$\mathcal{S}_{\text {https://doi.org/10.3765/sp.13.12 }}^{\text {Semantics \& Pragmatics Volume 13, Article 12: 1-55, } 2020}$

\title{
Weak necessity without weak possibility: The composition of modal strength distinctions in Javanese*
}

\author{
Jozina Vander Klok \\ Universitetet i Oslo
}

\author{
Vera Hohaus \\ The University of Manchester
}

Submitted 2019-11-02 / First decision 2020-05-13 / Revision received 2020-06-30 / Second decision 2020-07-11 / Revision received 2020-07-22 / Accepted 2020-08-14 / Published 2020-11-05 / Final typesetting 2022-09-15

\begin{abstract}
This paper investigates the semantics of the suffix -NE in Javanese (Austronesian; Indonesia), bringing to light new findings to bear on the composition of modal strength distinctions. In a transparent manner, this functional morpheme derives weak necessity modals from strong necessity modals, but cannot attach to possibility modals to derive weak possibility. Javanese thereby takes a different compositional route to weak necessity than most Indo-European languages, which lexicalise modal strength distinctions or rely on counterfactual morphology. We propose a new type of domain restriction analysis for weak necessity to capture both the defining properties of weak necessity as well as the restriction in Javanese to only necessity modals. Specifically, we propose that -NE requires quantification over a nonempty subset of a minimal witness set for the original quantification. The Javanese data thus show that weak necessity is not a unified phenomenon across languages, and our analysis contributes to a model of crosslinguistic variation concerning the relationship between gradability and modality, and the semantics of weak modal strength.
\end{abstract}

Keywords: modality, modal strength, weak necessity, crosslinguistic variation

* Matur nuwon to our Javanese speakers in Paciran, Mbak Deti Salamah, Mbak Finatty Ahsanah, Mbak Bahrul Ulum, Mbak Nunung, Mbak Haris, Pak Nasrulloh, Pak Faiz, Pak Farihi, Pak Khoim, Pak Khoiq, and the participants of the modal questionnaire. We would like to thank the three anonymous reviewers and the editors, Kai von Fintel and Magdalena Kaufmann, for valuable feedback on this paper. For comments and discussion, we would also like to thank Nadine Bade, Sigrid Beck, Paul Kroeger, Lisa Matthewson, Paula Menéndez Benito, Anne Mucha, Pablo Fuentes Opazo, Aynat Rubinstein, Konstantin Sachs, Hubert Truckenbrodt, and audiences at the LSA 2017 annual meeting in Austin, the 2017 DGfS workshop “Towards an Ontology of Modal Flavours" in Saarbrücken, the Manchester Semantics Lab, Oslo Linguistics, and the 2019 APLL meeting in Leiden.

(C)2020 Jozina Vander Klok, Vera Hohaus

This is an open-access article distributed under the terms of a Creative Commons Attribution License (https://creativecommons.org/licenses/by/3.o/). 
Jozina Vander Klok, Vera Hohaus

\section{Introduction}

The expression of modality in natural language can be descriptively characterised by three dimensions of meaning: modal force (necessity versus possibility), modal flavour (e.g., epistemic versus root), and modal strength (strong versus weak). The larger research question behind this paper is the composition of modal strength distinctions across languages. For English, such a difference in the strength of necessity is perceived in comparing ought and must, which (1) picks up on.

(1) Employees must wash their hands.

Non-employees really ought to wash their hands, too.

(von Fintel \& Iatridou 2008: p. 115)

Languages appear to rely on two strategies to weaken a necessity modal (von Fintel \& Iatridou 2008): They might lexicalise this weak necessity meaning (like present-day English) or derive weak necessity modals from their strong counterparts using counterfactual morphology (like French). Yet, beyond von Fintel \& Iatridou (2008), there has been little crosslinguistic research on modal strength.

In this paper, we discuss original fieldwork data from Javanese (Austronesian, Malayo-Polynesian; Indonesia), which uses yet another strategy: The language has a dedicated functional morpheme, -NE, which combines with a strong necessity modal to derive a weak one. An example is in (2). ${ }^{1}$ The language is thus morphologically and compositionally maximally transparent in deriving weak necessity modality. However, the change in modal strength is restricted to strong necessity: -NE cannot occur with possibility modals to derive weak possibility, as demonstrated in (3).

(2) Wong wong jawa kudu-ne iso ngomong kromo, person person Java ROOT.NEC-NE CIRC.POS AV.talk high.speech

terus anak-e rojo yo kudu iso.

then child-DEF king PRT.YES ROOT.NEC CIRC.POS

'Javanese people ought to be able to speak Krama, and the Sultan's son has to be able to.'

(3) a. Aku iso ngelangi.

ISG CIRC.POS AV.swim

'I can swim.'

1 See page 47 for a list of abbreviations used in glosses. 
Weak necessity without weak possibility
b. *Aku iso-ne ngelangi.
1SG CIRC.POS-NE AV.swim
(Int.) 'There is a slight possibility that I can swim.'

We propose an analysis that follows some of the guiding ideas of von Fintel \& Iatridou (2008) and Rubinstein (2012, 2014), who propose to model weak necessity as quantification over a subset of the favoured worlds. We pursue a different compositional implementation of these ideas, however, to derive weak necessity without weak possibility: -NE encodes universal quantification over a non-empty subset of a minimal witness set for the quantifier it attaches to. Necessity modal expressions only have one witness set, the set of favoured worlds. Minimal witness sets for possibility modal expressions are singleton sets, and thus do not make available any subsets that meet the requirements, hence the unacceptability of -NE with possibility modals.

The paper is organised as follows: In Section 2, we discuss the crosslinguistic literature and approaches to deriving weak modal strength, focusing on domain restriction and degree-based analyses of weak necessity. Section 3 discusses our methodology, and provides some background on the language, including the modal system of Javanese as spoken in Paciran, an East Javanese variety. Section 4 constitutes the empirical core of the paper: It presents the data on how Javanese -NE derives weak necessity (but not weak possibility), and is otherwise not counterfactual morphology. Section 5 spells out the domain restriction analysis we propose and shows how this analysis also captures the distributional restrictions of -NE. In this section, we also revisit the existing approaches, showing that the Javanese data present problems for existing domain restriction approaches as well as for degree-based approaches to weak necessity. Section 6 concludes, and Section 7 outlines some directions for further research, both within Malayo-Polynesian linguistics and crosslinguistically.

\section{Modal strength distinctions}

We first provide in Section 2.1 the background on the approach to modality in general that is used in this paper, and then hone in on weak necessity and how to define it in Section 2.2. In Section 2.3, we then introduce two different approaches to weak modal strength, domain restriction approaches and degree approaches. We conclude with a discussion of the little research there is on weak modal strength across languages in Section 2.4. 


\subsection{The quantificational analysis of modality}

Our starting point is a quantificational analysis of modality in English (for recent overviews, see Portner 2009, Hacquard 2011, Matthewson 2016). Under this analysis, there are at least two dimensions to modal meaning, modal force and modal flavour. Possibility modals like English can existentially quantify over possible worlds, while necessity modals like English must universally quantify over possible worlds. English thus lexically differentiates between these two types of modal force. The domain of quantification in English is restricted both lexically and contextually, giving rise to what we perceive as distinct flavours. Under the view developed in Kratzer 1977, 1978, 1981, 1991 and subsequent work, the domain restriction is composed in a step-wise fashion from an accessibility relation and an ordering source, as illustrated in Figure 1. A contextually provided (and potentially lexically restricted) accessibility relation allows us to select an initial subset of the set of possible worlds (Steps 1 and 2), say the worlds compatible with what the speaker knows under an epistemic reading. From this set, we select as the domain of quantification those worlds which are ranked highest with respect to a contextually provided ordering source (Steps 3 and 4 ). ${ }^{2}$ We follow von Fintel \& Iatridou (2008: p. 177) in referring to these worlds as the "favoured worlds".

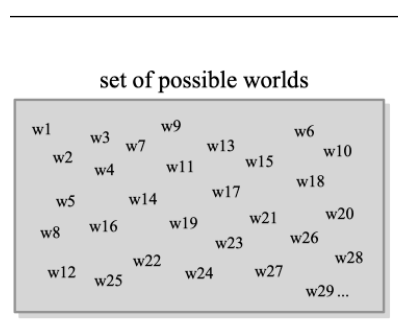

STEP 1

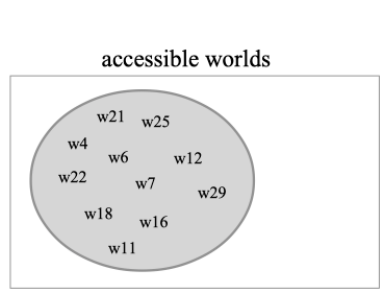

STEP 2

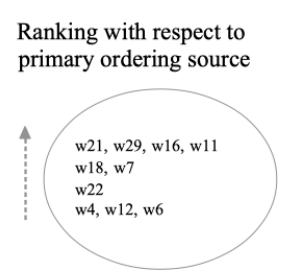

STEP 3
Selection of

highest ranked worlds

w21, w29, w16, w11

w18, w7

w22, w12, w6

STEP 4

Figure 1 Composing modal quantification domains

2 Unlike Lewis $(1973,1981)$ and Kratzer $(1981,1991)$ we assume for simplicity that there are such worlds (see also Stalnaker 1984). For a recent critical discussion of this limit assumption, see Kaufmann 2017. As one reviewer correctly points out, the visualisation in Figure 1 and the definition to follow in (6) assume that the ordering relation induces a strict ordering of worlds, rather than just a pre-order. This is ultimately a presentational choice. We would also like to thank one of our editors, Magdalena Kaufmann, for discussion relating to this choice and its consequences. 
Weak necessity without weak possibility

Under such a quantificational analysis, possibility and necessity modals have the lexical entries in (4), and rely on LF structures of the schematic form in (5) (see also von Fintel \& Heim 2011, von Stechow \& Beck 2015). ${ }^{3}$

(4) a. $\quad \llbracket$ (possibility modal) $\rrbracket=\lambda a_{\langle s, t\rangle} \cdot \lambda o_{\langle\langle s, t\rangle, t\rangle} \cdot \lambda p_{\langle s, t\rangle}$. $\exists w^{\prime} \in \operatorname{BEST}(a, o): p\left(w^{\prime}\right)=1$

b. $\quad \llbracket$ (necessity modal) $\rrbracket=\lambda a_{\langle s, t\rangle} \cdot \lambda o_{\langle\langle s, t\rangle, t\rangle} \cdot \lambda p_{\langle s, t\rangle}$. $\forall w^{\prime} \in \operatorname{BEST}(a, o): p\left(w^{\prime}\right)=1$

(5)

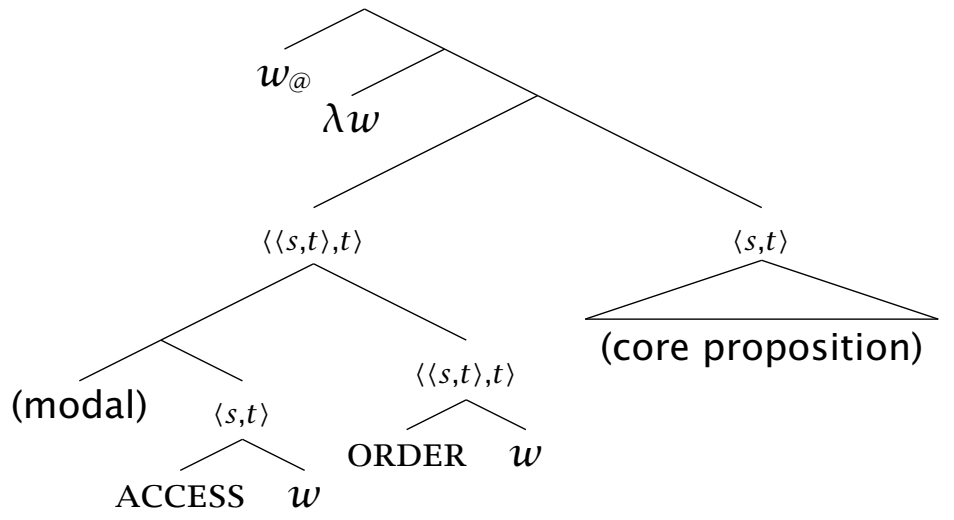

The ordering source, represented as ORDER in (5), is a contextually provided function that assigns to the world of evaluation a set of propositions that are used to define a strict order $>$ on the set of accessible worlds, provided by the relational accessibility function, represented as ACCESS in the LF structure above. A world $w$ is ranked higher than a world $w^{\prime}$ with respect to a set of propositions $P$ if and only if the propositions $w^{\prime}$ makes true form a subset of the propositions $w$ makes true, as in (6). A maximality operator, BEST, defined in (7), selects the best worlds from the accessible worlds with respect to the ordering source. Quantification is over the best of the accessible worlds, the favoured worlds.

(6) For any set of worlds $W \in D_{\langle s, t\rangle}$ and set of propositions $P \in D_{\langle\langle s, t\rangle, t\rangle}$ : $\forall w, w^{\prime} \in W: w>_{P} w^{\prime}$ iff $\left\{p \in P: p\left(w^{\prime}\right)=1\right\} \subset\left\{p^{\prime} \in P: p^{\prime}(w)=1\right\}$

(see also von Fintel \& Heim 2011: p. 61, no.(107))

3 We opt here for syntactically representing worlds as well as the accessibility relation and ordering source. The actual world $w_{@}$ is syntactically represented in the highest layer of the clause, following ideas in Kusumoto 1999, 2005. We assume that binding constraints require that the accessibility relation and the ordering source are interpreted relative to the same world (see also Percus 2000, Keshet 2008). 
(7) For any set of worlds $W \in D_{\langle s, t\rangle}$ and set of propositions $P \in D_{\langle\langle s, t\rangle, t\rangle}$ : $\operatorname{BEST}(P)(W)=\left\{w \in D_{s}: \neg \exists w^{\prime} \in W: w^{\prime} \neq w \& w^{\prime}>_{P} w\right\}$

While English modal expressions under this analysis are specified for their modal force, they may additionally exhibit some restrictions as to the modal flavours they allow. Unlike must and can, for instance, might is generally taken to not allow for deontic flavours (see, e.g., von Fintel \& Gillies 2007). Other languages show more flexibility when it comes to the force of their modal expressions (von Fintel \& Matthewson 2008): St'át'imcets (Salishan; Canada) lexicalises the distinction between modal flavours, but exhibits variable modal force (Rullmann, Matthewson \& Davis 2008). Washo (isolate; United States) modal suffix $-e$ ? behaves variably with respect to force and flavour (Bochnak 2015). Gitksan (Tsimshianic; Canada) exhibits variable force with epistemic flavours (Peterson 2010, Matthewson 2013). Nez Perce (Penutian, United States) also exhibits variable force effects (Deal 2011). It is important to note, though, that in all of these languages, the observed variability does not translate to an underspecification of the quantificational force in the lexical entry of those modal expressions. Rather, these modals have been analysed as encoding either existential or universal quantification, and variable force is due to pragmatic effects. Previewing some of the discussion in Section 3.3, the modal system of Javanese lexicalises force distinctions, and all modal markers exhibit restrictions as to the flavours they allow (Vander Klok 2012, 2013).

\subsection{Weak modal strength}

The semantics outlined in the previous section, however, does not yet capture that possibility and necessity are in principle gradable notions, and that both necessity and possibility modal expressions appear to exhibit strength distinctions. Present-day English, for instance, lexicalises ought or should apart from must. Intuitively, the modal claim in (8a) is somehow weaker than the modal claim in (8b). Similar intuitions - but admittedly more subtle - are also reported for could as opposed to can in (9). ${ }^{4}$ Although these strength distinctions, and in particular weak necessity modality, have only more re-

4 We would like to thank one of our reviewers for drawing our attention to these examples from the Cambridge Dictionary's "English Grammar Today" (URL: https://dictionary.cambr idge.org/grammar/british-grammar/can-could-or-may, last accessed 1st October 2019). 
Weak necessity without weak possibility

cently become the focus of a more sustained research effort, they have been featured in both the philosophical and linguistic literature. ${ }^{5}$

(8) a. Mary \{ought to/ should\} attend the meeting.

b. Mary must attend the meeting.

(9) a. It could be dangerous to cycle in the city.

b. It can be dangerous to cycle in the city.

Setting weak possibility aside for a moment, what characterises weak necessity? And how can we reliably identify weak modal strength in a fieldwork setting? We follow here a definition by Rubinstein (2020), who proposes to characterise weak necessity as in (10). We use this working definition in Section 4 to identify weak necessity modality in Javanese. (Note that this definition crucially relies on the existence of modal force distinctions in a language.)

(10) A modal word $\alpha$ is a weak necessity modal if (i) to (iii) hold, for any proposition $p$.

(i) The conjunction of $\alpha(p)$ and $\alpha(\neg p)$ is a contradiction.

(ii) There is a necessity modal $\beta$ such that $\beta(p)$ entails $\alpha(p)$.

(iii) There is a possibility modal $\gamma$ such that $\alpha(p)$ entails $\gamma(p)$.

The first part of the definition establishes that a weak necessity modal behaves like a necessity modal, but not like a possibility modal: Only possibility modals allow the conjunction of two mutually exclusive propositions, see (11a) below. English should and must pattern alike when it comes to the conjunction of mutually exclusive propositions: The resulting sentences are contradictory, when the domain restriction is kept constant, as is shown in (11b) and (11c).

5 In the philosophical literature, see, e.g., Sloman 1970, Wertheimer 1972, Jones \& Pörn 1986, McNamara 1996, Wedgwood 2006, Swanson 2008, Finlay 2009, 2010, Kolodny \& MacFarlane 2010, Yalcin 2016, and Silk 2019. In the linguistic literature, see, e.g., Horn 1972, Rivière 1981, Kratzer 1991, Sæbø 2001, Copley 2004, Ninan 2005, von Fintel \& Iatridou 2008, Lassiter 2011, 2017, Rubinstein 2012, 2014, 2020, Klecha 2014, Portner \& Rubinstein 2016, and Matthewson \& Truckenbrodt 2018. 
(11) Context: It is raining. I know that Anne doesn't care about the weather; she will go about her business as usual.

a. Anne may be inside and she may be outside.

b. \#Anne must be inside and she must be outside.

c. \#Anne should be inside and she should be outside.

The latter two parts of the definition establish that weak necessity is different from both necessity and possibility modals using entailment (see also Jones \& Pörn 1986). Thus, in (12), if it is true that Jordan must stay inside, then is it also true that Jordan should stay inside, but not vice versa. And similarly, if it is true that Jordan should stay inside, then is it also true that Jordan may stay inside, but not vice versa.

Context:

It is raining cats and dogs. Jordan's mom is worried about him getting sick. She tells her partner:

Jordan must stay inside.

$\leadsto$ Jordan should stay inside.

u Jordan may stay inside.

These entailment relations also show up in the scalar implicature that weak necessity modals may give rise to: I ought to help the poor in (13) gives rise to the implicature that the strong necessity modal claim is false. As shown in (13a) to (13c) from Silk (2019: p. 23), this implicature may be cancelled, reinforced or suspended. ${ }^{6}$

(13) I ought to help the poor.

a. In fact, I must.

[ cancellation]

b. But I don't have to.

c. Maybe I have to.

[reinforcement ]

[ suspension]

\subsection{Two approaches to modal strength distinctions}

We review here what we consider to be the two most prominent lines of approaches to weak modal strength, the domain restriction approach (most

6 Silk (2019) however ultimately rejects that for any proposition $p$, must $p$ entails ought $p$, and ought $p$ entails may $p$, at the very least under the epistemic reading. See also Yalcin 2016 for discussion of whether weak necessity should and ought even allow for true epistemic readings in the first place. 
Weak necessity without weak possibility

notably, von Fintel \& Iatridou 2008, Rubinstein 2012, 2014), and the degreebased approach (notably, Lassiter 2011, 2017, Portner \& Rubinstein 2016). ${ }^{7}$ We end up adopting a new variant of a domain restriction approach for Javanese weak necessity modality, which we present in Section 5.

Domain restriction approaches. The idea behind domain restriction approaches to weak necessity modality is quite simple, despite differences in the technical implementation (for an overview, see Rubinstein 2020). As von Fintel \& Iatridou (2008: p. 118) put it for weak necessity modals: "What makes them weaker semantically is that they have a smaller domain of quantification: Strong necessity modals say that the prejacent is true in all of the favoured worlds, while weak necessity modals say that the prejacent is true in all of the very best (by some additional measure) among the favoured worlds." We present an implementation of such a domain restriction approach in (14) and (15), where the additional restriction comes about through a secondary ordering source (see also von Fintel \& Iatridou 2008, Rubinstein 2014).

(14) $\llbracket$ (weak necessity modal) $\rrbracket=\lambda a_{\langle s, t\rangle} \cdot \lambda o 1_{\langle\langle s, t\rangle, t\rangle} \cdot \lambda o 2_{\langle\langle s, t\rangle, t\rangle} \cdot \lambda p_{\langle s, t\rangle}$. $\forall w^{\prime}\left[w^{\prime} \in \operatorname{BEST}(o 2, \operatorname{BEST}(o 1, a)) \rightarrow p\left(w^{\prime}\right)=1\right]$

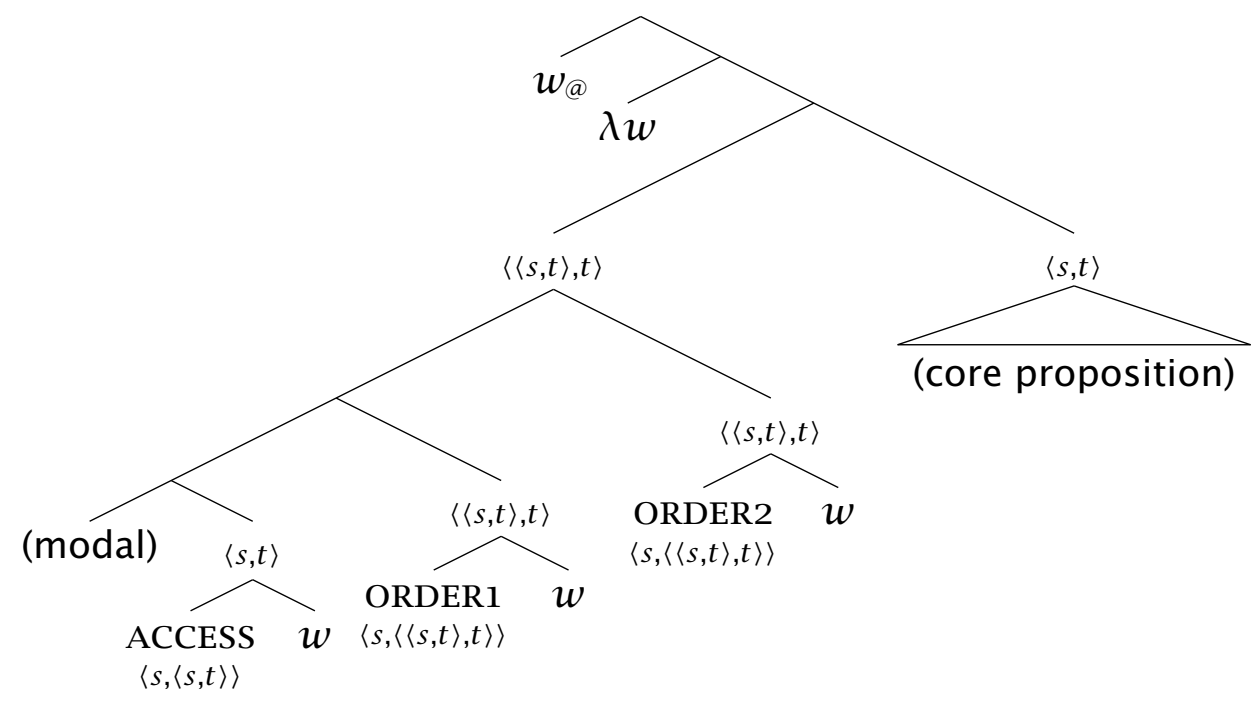

The weak necessity modal in (14) here has one more argument slot than a strong necessity modal to accommodate the additional ordering source,

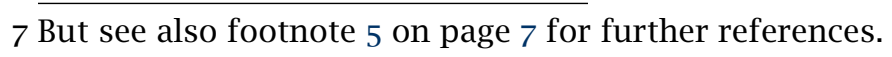


represented as ORDER2 in the Logical Form. Just like the accessibility relation and the primary ordering relation, the content of this restriction will be determined by the utterance context (discussed further below). The set of favoured worlds is then re-ranked according to this additional ordering source, and the highest ranked worlds are selected as the domain of quantification.

Building on Figure 1, we can then visualise the internal composition of the quantification domain of a weak necessity modal as in Figure 2, with an additional round of the ranking and selection process (Steps 5 and 6), resulting in a subset of the domain of quantification that the primary ordering source would derive.

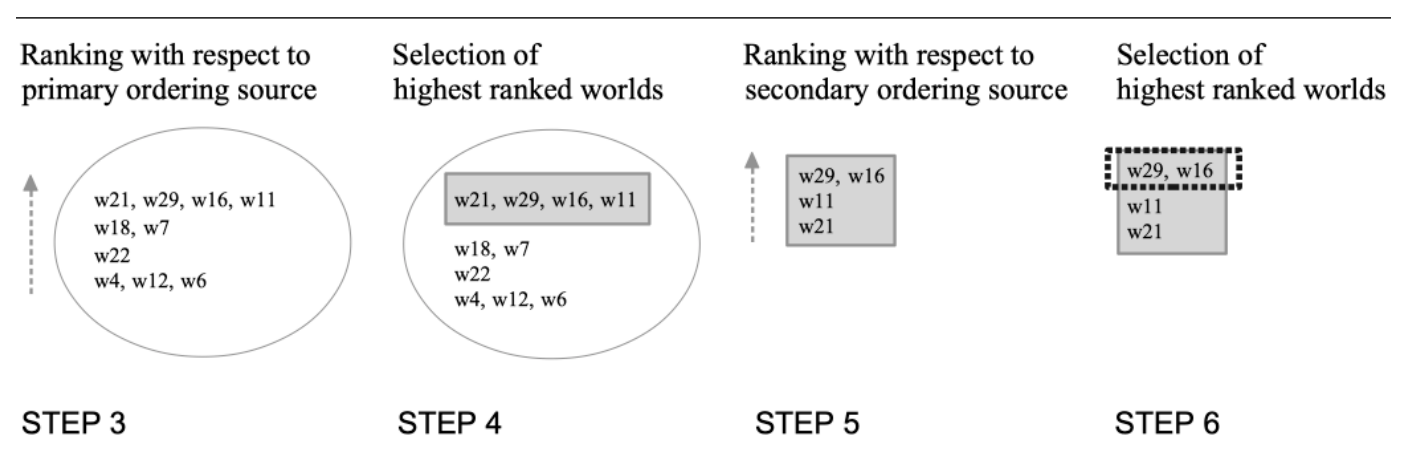

Figure 2 Composing quantification domains for weak modality

While intuitively appealing, the literature has identified two major challenges for domain restriction approaches, one conceptual, the other empirical: Conceptually challenging is the question of how to distinguish the accessible worlds and the ordering relation from the additional restriction (see also Silk 2019): "The success of the domain restriction approach to weak necessity depends on an ability to make finer-grained distinctions than are standardly assumed ..." (Rubinstein 2012: p. 39). Put differently, can the sets of worlds that may serve as the domain of quantification for a weak necessity modal also serve as the domain of quantification for a strong necessity modal in certain contexts? For instance, a proposition that serves to restrict the set of accessible worlds for a weak necessity modal could just as well be part of the propositions from which we derive the set of accessible worlds for a strong necessity modal, as spelled out in (16) under the assumption of an empty ordering source. As a result, quantification would be over the 
Weak necessity without weak possibility

same set of worlds irrespective of the strength of the modal (Rubinstein 2012: pp. 39-48).

(16) Assume $\operatorname{ACCESS}_{1}(w *)=p_{1} \cap p_{2} \cap p_{3}$

as well as $\operatorname{ACCESS}_{2}(w *)=p_{1} \cap p_{2}$ and $\operatorname{RESTRICT}(w *)=p_{3}$.

Then, $\operatorname{ACCESS}_{1}(w *)=\operatorname{ACCESS}_{2}(w *) \cap \operatorname{RESTRICT}(w *)$.

Rubinstein $(2012,2014)$ proposes that English weak necessity modals like ought and should (at least under their deontic interpretation) lexically specify that the additional domain restriction is derived from the set of propositions that are negotiable:

“...strong necessities are necessities relative to non-negotiable priorities, while weak necessities are necessities relative to negotiable priorities - raised and promoted by an opinionated individual. ... A priority is negotiable if it is not assumed that all members of a relevant group of individuals take it for granted."

(Rubinstein 2014: p. 537)

This analysis is motivated by examples such as (17). Unlike the context in (17a), the context in (17b) does not appear to license a strong necessity claim because “...it is not taken for granted that considerations of lawful conduct apply in the case of illegally employed workers. In contrast, such considerations are presupposed to guide the actions of those affiliated with a respectable university. Thus, moving to a conversation in which there is no commitment to the crucial priority appears to affect the choice of necessity modal." (Rubinstein 2012: p.52) 
(17) Context: Rachel is coming to the United States next summer. It is now illegal not to have health insurance.

a. [Rachel will be a graduate student at a respectable university.]

(i) She has to get health insurance.

(ii) ?She should get health insurance.

b. [Rachel will be employed illegally, selling cheap jewelry at a shopping mall.]

(i) She should get health insurance.

(ii) \#She has to get health insurance.

(Rubinstein 2012: p. 52, no. (40))

Another example that brings out this intuition is (18). As Rubinstein (2014) discusses, if uttered by an accountant with the company that is known for their integrity, we get an inference that other company officials might not be as committed to obeying the law. Uttered by a manager, we might infer that they are contemplating tax evasion. Rubinstein (2014: p. 538) writes that, in both cases, "... the tax law is portrayed as a negotiable ideal for some discourse participant, and in both cases the speaker is opinionated about the best course of action in the situation: he or she draws attention to an ideal and is taken to be promoting it."

(18) [Preparing a company's tax report.]

We should report all of our revenue.

(Rubinstein 2014: p. 538, no. (45))

Rubinstein (2012, 2014) implements this idea as a selectional restriction on the additional ordering source that weak necessity modals combine with (and thus as a definedness condition). Recourse to negotiability as a defining feature of weak necessity modality does address the conceptual worries of what characterises the additional domain restriction that brings about the weakening in the strength of the modal. Negotiability and speaker commitment however also feature in degree-based approaches (in particular Portner \& Rubinstein 2016) as well as in Silk 2019, to which we will return in a moment. Before we do, let us review an empirical worry regarding domain restriction approaches.

Even though the existing research literature on modal strength distinctions almost exclusively focuses on weak necessity, possibility, too, may be perceived as a gradable notion and thus exhibit strength differences (Riv- 
Weak necessity without weak possibility

ière 1981, Kratzer 1991, Lassiter 2011, 2017, Klecha 2014). In English, this is particularly visible when we consider adjectival and nominal expressions of modality, as in (19) and (20), but recall (9) from Section 2.2 as well.

(19) a. It is barely possible to climb Mount Everest without oxygen.

b. It is easily possible to climb Mount Toby.

(Kratzer 1991: p.643, no.(18))

(20) a. There is a good possibility that Michl is the murderer.

b. There is a slight possibility that Michl is the murderer.

(Kratzer 1991: p.643, no.(19))

(9) a. It could be dangerous to cycle in the city.

b. It can be dangerous to cycle in the city.

Domain restriction approaches are not amenable to an analysis of weak possibility (see also Silk 2019: pp. 16-17): If we were indeed to assume that weak modal strength is about acknowledging the negotiability of a set of propositions that are used to derive the favoured worlds, this type of possibility modal expression should in fact be stronger than its plain counterpart, contrary to our intuitions about can as opposed to could. ${ }^{8}$ More specifically, for any proposition $p$ and any two sets of favoured worlds $W$ and $W^{\prime}$, where $W^{\prime} \subset W$, there is a world $w \in W^{\prime}$ such that $p(w)=1$ logically entails that there is a world $w \in W$ such that $p(w)=1$, but not vice versa. We will see that in Javanese, however, the morphology used to weaken a necessity modal, when used on a possibility modal, neither results in the strengthening predicted under the domain restriction approach nor in the weakening actually observed for English, but rather in unacceptability, as previewed above in (3).

Degree-based approaches. Weak modal strength has more recently also been discussed as one facet of a more general phenomenon, that of the gradability of modal expressions and their acceptability in comparison constructions (Villalta 2008, Yalcin 2010, Lassiter 2011, 2017, Klecha 2014, Herburger \& Rubinstein 2014, 2019, Solt 2015, Portner \& Rubinstein 2016, Rubinstein 2020, Hohaus 2021). Data like (21) are suggestive of analysing at least

8 Note that Rubinstein (2012)'s analysis is built on the assumption that English does not lexicalise weak possibility. On the question whether weak possibility modals exists, Rubinstein (2012: p. 102) writes: "The null hypothesis would be that they do, and that we might be able to find an existential counterpart to ought in languages that grammatically distinguish between weak and strong necessity." 
some modal expressions of English with the tools developed for the analysis of gradable adjectives like tall in (22).

(21) a. I need to go on vacation more than I need to finish this work.

(Solt 2015: p. 20, no. (18))

b. It is just as likely that Barbara will win as it is that Alice will win. (Portner \& Rubinstein 2016: p. 257, no. (6c))

c. How necessary is it to marinate meat before making jerkies? (Lassiter 2017: p. 1, no.(1.1a))

(22) a. Martina is tall.

b. Martina is taller than Delia.

c. Ryan is as tall as Delia.

d. How tall is Simone?

Under standard accounts (e.g., von Stechow 1984, Heim 2001, Kennedy 1997, Beck 2011), gradable adjectives in English have the semantics in (23a) and establish a relation between an entity and a measurement degree; at their core is a measurement function like HEIGHT. In the unmarked positive case in (22a), the degree argument is closed off by a covert operator like (23b), which relates the maximal degree to which an entity has some property to a contextually salient standard (for further discussion, see von Stechow 1984, 2009, Fults 2006, Kennedy 2007). The resulting interpretation is in (23c). Other degree operators include the comparative (encoding the greater-than relation) and the equative (encoding the greater-than-or-equal relation).
a. $\llbracket \sqrt{\text { tall }} \rrbracket=\lambda w \cdot \lambda d \cdot \lambda x . \operatorname{HEIGHT}(w)(x) \geq d \quad$ (type $\langle s,\langle d,\langle e, t\rangle\rangle\rangle)$
b. $\llbracket \operatorname{POS}_{\text {(simplified) }} \rrbracket^{c}=\lambda R_{\langle d,\langle e, t\rangle\rangle} \cdot \lambda x \cdot \operatorname{MAX}(\lambda d \cdot R(d)(x)=1)>\operatorname{STD}_{c}$
c. $\quad\left[\left[w_{@}\left[\lambda w\left[\right.\right.\right.\right.$ Martina $\left[\right.$ is $\left.\left.\left.\left.\left[\mathrm{AP}_{\mathrm{AP}}[\mathrm{DegP} \operatorname{POS}]\left[\mathrm{A}_{\mathrm{A}} \operatorname{tall}_{w}\right]\right]\right]\right]\right]\right] \rrbracket^{c}=1$ iff $\operatorname{MAX}\left(\lambda d\right.$. HEIGHT $\left(w_{@}\right)($ Martina $\left.) \geq d\right)>\operatorname{sTD}_{c}$
'The maximal degree to which Martina is tall exceeds the contextual standard for tallness.'

Extending this analysis to weak necessity modals like should will assign them a semantics under which they relate propositions to degrees, as in (24). Suggestions as to the underlying scale that the measure function $\mu$ in (24) operates on include measures of probability of achieving a certain outcome (Finlay 2009, 2010), of utility with respect to a certain goal (Lassiter 2011, but see 
Weak necessity without weak possibility

Lassiter 2017), and of compatibility with the speaker's negotiable priorities (Portner \& Rubinstein 2016).

(24) $\llbracket \sqrt{\text { should }} \rrbracket=\lambda w \cdot \lambda d \cdot \lambda p_{\langle s, t\rangle} \cdot \mu(w)(p) \geq d \quad$ (type $\left.\langle s,\langle d,\langle\langle s, t\rangle, t\rangle\rangle\rangle\right)$

Generalising across the different proposals, the example in (25) says that the addressee calling Barbara is ranked higher on the underlying scale than the addressee calling Alice, and can be analysed in a structurally parallel fashion to any other clausal comparative.

(25) Weak necessity comparatives

a. You should call Barbara more than (you should call) Alice.

(Portner \& Rubinstein 2016: p. 257, no. (6a))

b. Logical Form:

[ $w_{@}\left[\lambda w\right.$ [ [Degp more $\left[\lambda d^{\prime}\left[\operatorname{should}_{w, d^{\prime}}\left[\lambda w^{\prime}\right.\right.\right.$ you call $w_{w^{\prime}}$ Alice $\left.\left.\left.]\right]\right]\right]$

$\left[\lambda d\left[\operatorname{should}_{w, d}\left[\lambda w^{\prime \prime}\right.\right.\right.$ you call $w_{w^{\prime \prime}}$ Barbara $\left.\left.\left.\left.\left.]\right]\right]\right]\right]\right]$

c. Clausal comparative operator:

$\llbracket$ more $\rrbracket=\lambda D_{\langle d, t\rangle}^{\prime} . \lambda D_{\langle d, t\rangle} . \operatorname{MAX}(D)>\operatorname{MAX}\left(D^{\prime}\right)$

d. Truth conditions:

$\mu_{w_{@}}(\lambda w$. ADDRESSEE call Barbara in $w)>$

$\mu_{w_{\circledast}}\left(\lambda w^{\prime}\right.$. ADDRESSEE call Alice in $\left.w^{\prime}\right)$

Degree-based approaches vary in their analysis of the unmarked case (that is, of plain should), and more specifically in their assumptions as to the standard of the comparison in this case. Like Klecha (2014), Portner \& Rubinstein (2016: p. 276) assume that a covert Positive operator will close off the degree argument just as in (23) above, and relate it to a contextually provided standard for negotiable necessity, as sketched in (26) and (27). In contrast, Villalta (2008) assumes that comparison is with a set of alternative propositions in the context and proposes a null operator that is essentially a superlative (see also Finlay 2009, 2010). We sketch an implementation of such an analysis in (28).

(26) a. You should call Barbara.

b. Logical Form:

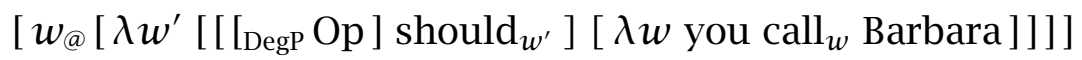


(27) Unmarked weak necessity as Positive:

a. Covert operator:

$\llbracket \mathrm{Op} \rrbracket^{c}=\lambda R_{\langle d,\langle s t, t\rangle\rangle} \cdot \lambda p_{\langle s, t\rangle} \cdot \operatorname{MAX}(\lambda d \cdot R(d)(p)=1)>\operatorname{STD}_{c}$

b. Truth conditions:

$\mu_{w_{@}}(\lambda w$. ADDRESSEE call Barbara in $w)>\operatorname{STD}_{c}$

(28) Unmarked weak necessity as superlative:

a. Covert operator:

$\llbracket$ Op $\rrbracket^{c}=\lambda R_{\langle d,\langle s t, t\rangle\rangle} \cdot \lambda p_{\langle s, t\rangle} \cdot \forall q[q \in C \& q \neq p \rightarrow$

$\left.\operatorname{MAX}(\lambda d \cdot R(d)(p)=1)>\operatorname{MAX}\left(\lambda d^{\prime} . R\left(d^{\prime}\right)(q)=1\right)\right]$

b. Truth conditions:

$\forall q[q \in C \& q \neq[\lambda w$. ADDRESSEE call Barbara in $w]$

$\rightarrow \mu_{w_{@}}(\lambda w$. ADDRESSEE call Barbara in $\left.w)>\mu_{w_{\Theta}}(q)\right]$

While we won't discuss the differences between these two approaches in detail here, note that (27) allows for higher ranked propositions in the context and will be true if calling Barbara is an acceptable or good enough alternative. The truth conditions in (28) exclude this option, and require that the prejacent be higher ranked than all contextually salient alternative propositions.

Compared to domain restriction approaches, degree-based approaches to weak modal strength are attractive because they allow for a uniform analysis of comparison constructions, modal or not, and predict gradable necessity as well as possibility. Previewing some more of our findings for Javanese, however, necessity modal expressions suffixed by -NE (even though adverbial) are unacceptable in comparison constructions, and we will not pursue a degreebased analysis. The data from Javanese thus point to potentially interesting variation in the composition of weak modal strength across languages.

\subsection{The crosslinguistic picture}

From von Fintel \& Iatridou (2008)'s informal survey of nine languages spoken in Eurasia, ${ }^{9}$ there emerge two strategies for linguistically encoding weak necessity (see also Rubinstein 2014): Under the first strategy, weak necessity is lexicalised, as in the case of ought or should in English (even though it

9 Von Fintel \& Iatridou (2008) discuss weak necessity in Hungarian (Uralic) and in eight IndoEuropean languages from different genera (English, Dutch, Icelandic, Greek, French, Spanish, Russian, and Croatian). 
Weak necessity without weak possibility

is a result of grammaticalisation in this case). Under the second strategy, a strong necessity modal receives a weak interpretation when combined with the morphology also used to mark counterfactuality. We find this strategy in French, for instance, as shown in (29). Here, the necessity modal devoir is in the conditional mood (le mode conditionnel), which crucially is also used in the consequent of a counterfactual conditional like (30).

$\begin{array}{lll}\mathrm{Tu} \text { dev-rais faire la vaisselle, } & \text { - French- } \\ \text { you NEC-COND.2SG.PRES do.INF the dishes } & \end{array}$
mais tu n'es pas obligé.

but you not+are not obliged

'You ought to do the dishes, but you are not obliged to do them.'

(von Fintel \& Iatridou 2008: p. 121, no. (15))

(30) Il n'est pas soûl. Si il etait soûl, il parl-erait plus he not+is not drunk if he were drunk he talk-COND.3SG.PRES more fort.

loud

'He isn't drunk. If he were drunk, he would talk more loudly.'

(von Fintel \& Iatridou 2008: p. 122, no. (18))

The two strategies are not mutually exclusive, however: Present-day Dutch (Indo-European, Germanic) appears to have lexicalised a weak necessity modal, horen, as exemplified in (31). Weak necessity may additionally be expressed with the help of conditional zou, as in (32). As is the case with counterfactual morphology in French, zou also appears in the consequent of counterfactual conditionals like (33).

(31) Je hoort dat zo te doen. -Dutchyou NEC(weak) this so to do

'You should do it this way.'

(32) a. Je zou eens Anna Karenina moeten lezen, maar het hoeft you would once Anna Karenina must read but it must niet.

not

'You should read Anna Karenina some time, but you don't have to.' 
b. \#Je moet Anna Karenina lezen, maar het hoeft niet.

you must Anna Karenina read but it must not

'You have to read Anna Karenina, but you don't have to.'

(von Fintel \& Iatridou 2008: p. 124, no. (31)-(32))

(33) Als ik rijk was, zou ik stoppen met werken.

if I rich were would I stop with work

'If I were rich, I would stop working.'

(von Fintel \& Iatridou 2008: p. 124, no. (30))

von Fintel \& Iatridou (2008: p. 126) conclude “...that it is a crosslinguistically stable fact that the meaning of OUGHT can be conveyed with counterfactual morphology on a strong necessity modal." Note that this conclusion is phrased as a possibility rather than a necessity statement, and von Fintel \& Iatridou (2008: p. 124) are careful to point out that they “.... are not claiming that all the world's weak necessity modals are formed by counterfactual marking on strong necessity modals." The two strategies, counterfactual marking and lexicalisation, are thus not mutually exclusive, and may very well not be exhaustive. We would expect there to potentially be other strategies to weaken the strength of a modal across languages.

For the languages that von Fintel \& Iatridou (2008) discuss which use counterfactual marking, this morphology always co-occurs with the necessity modal. Other languages may well use alternative morphosyntactic strategies that do not involve the necessity modal since not all languages have lexicalized necessity modals in the first place (see, e.g., Narrog 2012: pp. 251-252), or because counterfactual marking to derive weak necessity is ruled out for independent reasons (see, e.g., Rubinstein 2014 on Modern Hebrew). We also would expect there to be languages that do not opt for using counterfactual marking or lexicalisation since there does not seem to be a reason why only these two strategies could derive weak necessity modality. We report such a strategy in Section 4 for Javanese. The language uses dedicated functional morphology to weaken the strength of a necessity modal and in this way transparently derives weak necessity from strong necessity. This morphology does not, however, mark counterfactuality. Before we turn to these data, we provide a brief background on the language and our fieldwork methodology, and introduce the modal system of Paciran Javanese. 
Weak necessity without weak possibility

\section{Background on Javanese}

\subsection{The Javanese language}

Javanese is an Austronesian language from the Malayo-Polynesian branch and primarily spoken in Central and East Java, Indonesia. With close to 70 million speakers, it is the largest language worldwide with no official status (Indonesian being the official national language). ${ }^{10}$ Dialects of Javanese are highly divergent, with three main dialectal groupings of West, Central and East Javanese (Nothofer 1981, Hatley 1984). In addition, Javanese has three speech levels, krama 'high', madya 'mid' and ngoko 'low', which are most prominent in the courtly cities of Yogyakarta and Surakarta/Solo (see, e.g., Poedjosoedarmo 1968, Smith-Hefner 1989, Errington 1998). Our data are from an East Javanese dialect spoken in Paciran village, Lamongan Regency, East Java. Paciran village is located on the North shore of East Java, near the town Tuban as shown on the map in Figure $3 .{ }^{11}$ The data in this paper are in ngoko 'low', which is the speech level most widely used in Paciran given its geographical distance from the Javanese courtly centers. The other speech levels are used to a lesser extent in Paciran but remain ideologically important (see also Vander Klok 2019).

The basic word order of modern Javanese is SVO, and verbal morphology marks a reduced symmetrical voice system, which indicates which thematic argument is the subject (see, e.g., Conners 2008, Robson 2014). All examples in this paper are in Actor Voice (AV), which is indicated by nasal substitution with a homorganic nasal prefix, as in (34) with mangan; compare pangan 'to eat'. Tense and aspect are realised optionally via free functional morphemes (see, e.g., Vander Klok 2012, Robson 2014).

\section{Kana (lagek) mangan bubur alon-alon.}

Kana PROG AV.eat rice.porridge RED-slowly

'Kana is eating rice porridge slowly.'

(Vander Klok 2012: p. 59, no. (58c))

10 It is difficult to ascertain the current speaker population. According to the 2010 census report (published by Badan Pusat Statistik), there are 68,044,66o self-reporting Javanese speakers age five years and above, from a population of 95,217,022 self-identified Javanese people. These numbers have been decreasing (Ravindranath \& Cohn 2014).

11 From CartoGIS, College of Asia and the Pacific, The Australian National University (URL: http://asiapacific.anu.edu.au/mapsonline/base-maps/java-base, last accessed ist March 2017). Licensed under Creative Commons Attribution-ShareAlike 4.o International. 


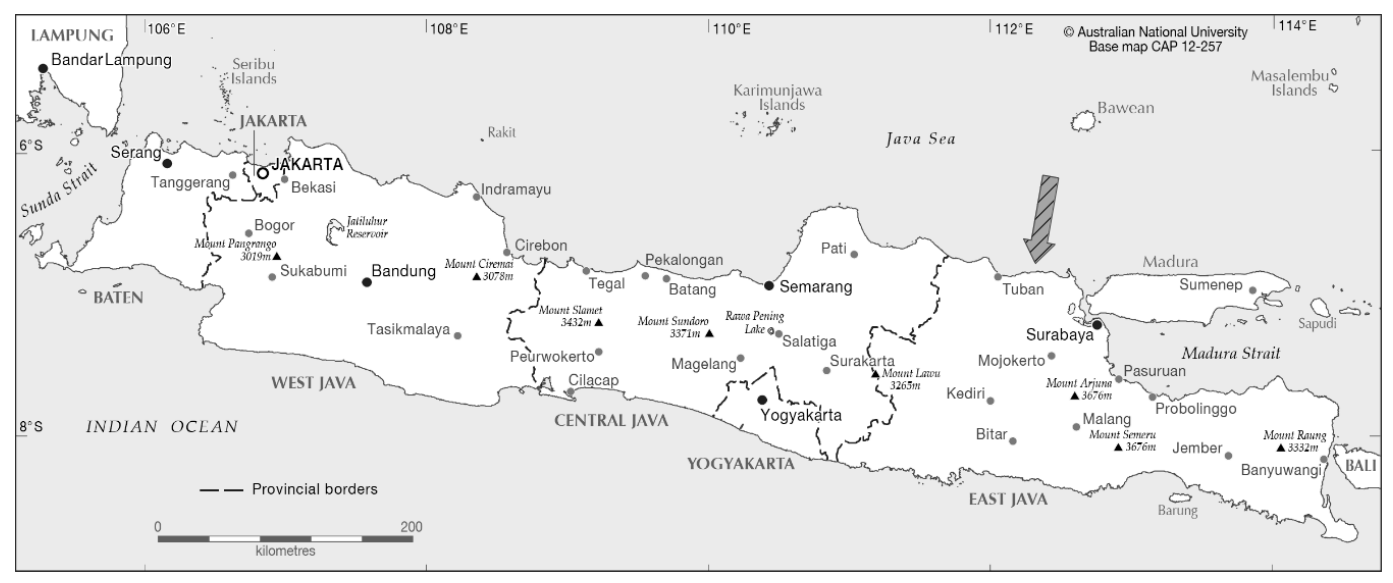

Figure 3 Map of Java Island and the location of the village of Paciran

Javanese is relatively understudied, and there is no previous formal research on the topic of this paper, the semantics of -NE and the modal strength distinction. This aspect of -NE has not received attention in the descriptive literature either, although Robson \& Wibisono (2002) do note a translationbased strength distinction between necessity modals with and without -NE in their dictionary. Other descriptive resources discuss only the morphosyntactic properties of -NE, and again, hint at strength distinctions in translations to Indonesian (Ekowardono et al. 1999, Wedhawati et al. 2006).

\subsection{Methodology}

All data presented in this paper are from original fieldwork conducted in Paciran, Java, Indonesia, by the first author from periods throughout 2011 to 2019. A variety of methods were used including recorded natural conversations as well as the semantic elicitation techniques described in Matthewson 2004, 2011, translation tasks, and storyboards (Burton \& Matthewson 2015). The elicitation judgments typically represent judgments from two to four language consultants. In some cases, individual speakers were asked to give acceptability judgments of sentences in an elicitation set, and then the same elicitation set was discussed individually with other speakers, who also gave acceptability judgments. In other cases, group elicitation sessions with two to four speakers were held. In asking for semantic judgments, a discourse context was constructed by the first author or offered by the lan- 
Weak necessity without weak possibility

guage consultants. Elicitation was almost exclusively conducted in the target language, and specifically, in the variety of Javanese spoken in Paciran. We follow Matthewson (2004) in that translation can only provide clues, not results, as to the contribution of meaning of a given morpheme. Where appropriate, translation tasks were either from Indonesian or English to Javanese; the contact language used for storyboards was English. Data also come from a questionnaire study on modality which was implemented as an acceptability judgment task using a likert scale (with ten participants) and a semiforced choice task (with 15 participants); see also Vander Klok 2012, 2013. ${ }^{12}$ The modal questionnaire was presented using only Paciran Javanese (for the instructions, contexts, and items). Unless stated otherwise, the examples in this paper are based on elicitation.

\subsection{The modal system of Paciran Javanese}

In order to understand the composition of weak necessity, we first give an overview of the modal system of Paciran Javanese focusing on the dimensions of force and flavour. ${ }^{13}$ With respect to these two dimensions of description, the Javanese modal system instantiates a mixed system, as illustrated in Table 1 based on Vander Klok 2013. While all modals are specified for either possibility or necessity, they vary as to the flavours they allow: The modal mesthi may only be interpreted as an epistemic necessity modal, while paleng may only be interpreted as an epistemic possibility modal. The modals oleh and iso are also lexically specified for possibility, but are only compatible with certain root modal flavours, just like the necessity modals $k u d u_{1}$ and $k u d u_{2}$. (See below for details on how the modal force and modal flavour were determined, illustrated with examples with the modal mesthi.)

In terms of their syntax, these modals do not form a uniform class. The epistemic modals mesthi and paleng are adverbs, while the root modals are auxiliaries, with one exception: The modal $k u d u_{2}$ is a main verb (Vander Klok 2012). ${ }^{14}$

12 For the modal questionnaire, see the Max Planck Institute for Evolutionary Anthropology's "Typological Tools for Field Linguistics" (URL: https://www.eva.mpg.de/lingua/tools-atlingboard/questionnaire/cross-linguistic-use.php, last accessed 9th August 2019). 13 See Ekowardono et al. 1999 for a description of modality in Standard Javanese.

14 Evidence for positing a lexical ambiguity for kudu in this variety of Javanese comes from VP-topicalisation and predicate negation (Vander Klok 2012): The auxiliary $k u d u_{1}$ disallows topicalisation and is located above negation, while main verb $k u d u_{2}$ can undergo topicali- 
Jozina Vander Klok, Vera Hohaus

\begin{tabular}{|c|c|c|c|c|c|c|}
\hline & \multicolumn{5}{|c|}{ flavour } \\
\hline & & \multirow{2}{*}{ EPISTEMIC } & \multicolumn{4}{|c|}{ ROOT } \\
\hline & & & deontic & circumstantial & teleological & bouletic \\
\hline \multirow{2}{*}{ force } & NECESSITY & mesthi & & $k u d u_{1}$ & & $k u d u_{2}$ \\
\hline & POSSIBILITY & paleng & oleh & iso & & - \\
\hline
\end{tabular}

Table 1 Modal force and flavour in the modal system of Paciran Javanese

With respect to modal force, mesthi is compatible with necessity, but not possibility contexts, as shown in (35) and (36). In the latter, the epistemic possibility modal paleng is used instead.

a. Context:

- NECESSITY -

Kana is reading in the car, but she always gets sick when she reads in a moving vehicle. You think:

b. Kana mesthi engko ndas-e ngelu.

Kana EPIS.NEC later head-DEF have.headache 'Kana will certainly have a headache later.'

a. Context:

- POSSIBILITY Dewi is looking for her necklace. She's not sure if she lost it or if it is still somewhere in the house because she doesn't remember the last time that she wore the necklace. She looks in her wardrobe and on top of the wardrobe. It's not there. She looks on top of the tv. It's not there. She looks in her backpack; it's not there. Wait! She didn't check her sister's wardrobe yet.

b. Kalung-e \{paleng/ \#mesthi\} ilang. necklace-DEF EPIS.POS EPIS.NEC lose 'Her necklace might be lost.'

Concerning the modal flavour of mesthi, it is only acceptable in epistemic contexts such as (37). Infelicity results when mesthi is tested in any other modal flavour context, be it deontic or circumstantial, as shown in (38) and (39). Instead, the root necessity modal $k u d u_{1}$ is most appropriate in both of these cases.

sation and occurs below negation. Due to its differential syntactic properties, we set $k u d u_{2}$ aside here (see also Section 4.1). 
Weak necessity without weak possibility

a. Context:

- EPISTEMIC -

"They can't be hiding in the box", says the policeman. "It's too small. And they can't be hiding under the bed. It's too low ..."15

b. Cah loro iku \{mesthi/ \#kudu\} sengidan

child two DEM EPIS.NEC ROOT.NEC hide

nek ngguri-ne selambu.

at behind-DEF curtain

'They must be hiding behind the curtain!'

a. Context:

- DEONTIC -

A while later, Mary gets better from her cold.

Her friends come over and ask her to come play outside.

Mary says, "Sorry, I can't come out to play ..."16

b. $P R-k u \quad\langle u w\rangle$ akeh yo

homework-my INT+many PRT.yes

$\{$ kudu/ \#mesthi $\}$ tak=kerjak-no.

ROOT.NEC EPIS.NEC 1SG.CL=work-APPL

'I have so much homework, I have to work on it!'

a. Context:

- CIRCUMSTANTIAL -

You are on the road to Yogya. You haven't had time to go pee for six hours; you really need to go. You send a text to your friend:

b. Aku $\{$ kudu/ \#mesthi $\}$ nguyoh!

1SG ROOT.NEC EPIS.NEC AV.pee

'I have to pee!'

Thus, the modal auxiliary mesthi lexically specifies both its modal force (as necessity), and its modal flavour (as epistemic). Similar tests were used for all the other modals in Table 1 to determine their force and flavour (see Vander Klok 2013 for details).

\section{Weak necessity in Javanese}

We now turn to strength distinctions, and to how weak necessity (but not possibility) is derived via suffixation by -NE. After a brief description of the morphosyntactic and phonological properties of -NE (Section 4.1), we show

15 Based on TFS Working Group (2011), “On the Lam,” Totem Field Storyboards (URL: http://to temfieldstoryboards.org/stories/on_the_lam/, last accessed 3rd October 2019).

16 Based on TFS Working Group (2011), "Sick Girl," Totem Field Storyboards (URL: http://tote mfieldstoryboards.org/stories/sick_girl/, last accessed 3rd October 2019). 
that -NE-marked modals meet the definition for weak necessity (Section 4.2), but that -NE is not counterfactual morphology (Section 4.3). We also discuss other properties of -NE that will be relevant for our analysis: Unlike counterfactual morphology in other languages, the suffix is restricted to those modals that encode necessity (Section 4.4 ), and its addition does not change the modal flavour of its root (Section 4.5).

\subsection{A note on the morphosyntax and phonological form of -NE}

Our focus in this paper is on suffixation with $-\mathrm{NE}_{1}$ (elsewhere just referenced as -NE), whose distribution is restricted to modal adverbs and auxiliaries. -NE-suffixed modals are always adverbial (Wedhawati et al. 2006: pp.331, 336). The form of this suffix is phonologically predictable: When the stem ends in a vowel, -ne appears, and elsewhere - $e$.

We set aside here a homonym with a distinct morphosyntax and semantics: $-\mathrm{NE}_{1}$ is homophonous with the clitic $-\mathrm{NE}_{2}$ in the nominal domain that marks definiteness, as in (40). (See also Section 7.1, where we discuss directions for future research.)

(40) Kucing-e $e_{2}$ nyolong iwak.

cat-DEF AV.steal fish

'The cat stole some fish.'

(Davies \& Dresser 2005: p. 61)

Assuming that Javanese has zero derivation, a nominal syntactic analysis for the weak necessity modals mesthi-ne and kudu-ne is ruled out for distributional reasons: While nouns can occur with pronominal possessive marking (like - $k u$ 'my'), the weak necessity modals cannot. Thus, "mesti-ku is ungrammatical and does not translate to 'my certainty', nor does *kudu-ku translate to 'my obligation'. The morphosyntactic restrictions on the distribution of - $\mathrm{NE}_{1}$ will be relevant for Section 4.3 , where we will use it as an argument against an analysis of $-\mathrm{NE}_{1}$ as counterfactual morphology.

\subsection{Meeting the definition of weak necessity}

In this section, we show that -NE-marked modals behave like weak necessity modals under the definition proposed by Rubinstein (2020), repeated here: 
Weak necessity without weak possibility

(10) A modal word $\alpha$ is a weak necessity modal if (i) to (iii) hold, for any proposition $p$.

(i) The conjunction of $\alpha(p)$ and $\alpha(\neg p)$ is a contradiction.

(ii) There is a necessity modal $\beta$ such that $\beta(p)$ entails $\alpha(p)$.

(iii) There is a possibility modal $\gamma$ such that $\alpha(p)$ entails $\gamma(p)$.

Like a necessity statement (but unlike the possibility counterpart), a -NE-marked modal cannot be true of both the prejacent and its negation, as required by the first condition of the definition in (10). We show this for epistemic modality in (41). We find the same pattern of acceptability judgments for deontic necessity, in (42). In both contexts, the two possibility statements with epistemic paleng and deontic oleh can be true. ${ }^{17}$

(41) a. Context: Your friend Lisa is visiting you at your house, and now it is after isya' [the fifth daily prayer call] and getting late. You offer to Lisa that she can sleep overnight at your house. You also offer to walk with her to her house. It is up to her to decide. It is fine either way. Your Mom asks: "Do you know what Lisa is going to do?" You reply:

b. \#Mbak Lisa mesthi-ne nginep nek kene;

Miss Lisa EPIS.NEC-NE AV.stay.overnight at here.

de'e yo mesthi-ne muleh.

3 PRT.YES EPIS.NEC-NE AV.go.home

'Lisa should stay here. She also should go home.'

c. \#Mbak Lisa mesthi nginep nek kene;

Miss Lisa EPIS.NEC AV.stay.overnight at here.

de'e yo mesthi muleh.

3 PRT.YES EPIS.NEC AV.go.home

'Lisa must stay here. She also must go home.'

d. Mbak Lisa paleng nginep nek kene;

Miss Lisa EPIS.POS AV.stay.overnight at here.

de'e yo paleng muleh. Aku durung ngerti.

3 PRT.YES EPIS.POS AV.go.home 1SG not.yet understand

'Lisa might stay here. She also might go home. I don't know yet.'

17 Note that it was not possible to use the Javanese conjunction lan 'and' since it is not acceptable in the Paciran Javanese variety; this conjunction is used in Central Javanese varieties. Instead, we used two individual sentences with the second containing the particle yo 'yes' in between the subject and the predicate. In this syntactic position, the particle necessarily receives an additive translation. 
(42) a. Context: The principal of the school has made a new rule: If a teacher teaches an extra class, they must teach it on the school grounds. It doesn't matter if the teacher wants to teach inside or outside. The important thing is that they stay on the school grounds. Mr. Sari is a new teacher. He is going to teach an extra English class in the morning before school begins. The principal tells Mr. Sari:

b. \#Sampean kudu-ne ngulang nek njobo;

2 ROOT.NEC-NE AV.teach at outside

Sampean yo kudu-ne ngulang nek njero.

$2 \quad$ PRT.YES ROOT.NEC-NE AV.teach at inside

'You ought to teach outside. You also ought to teach inside.'

c. \#Sampean kudu ngulang nek njobo;

2 ROOT.NEC AV.teach at outside

Sampean yo kudu ngulang nek njero.

$2 \quad$ PRT.YES ROOT.NEC AV.teach at inside

'You must teach outside. You also must teach inside.'

d. Sampean oleh ngulang nek njobo;

$2 \quad$ DEON.POS AV.teach at outside

Sampean yo oleh ngulang nek njero.

$2 \quad$ PRT.YES DEON.POS AV.teach at inside

'You may teach outside. You also may teach inside.'

We next present data that allow us to locate the meaning of a -NE-marked necessity modal with respect to both mere possibility and necessity, in accord with the conditions in (ii) and (iii) of the definition. We show examples primarily with the epistemic modals, but comparable examples can be constructed with the root necessity modal $k u d u_{1}$. Consider first the examples in (43). Each of these propositions are individually accepted in the context by speakers, showing that they are all compatible. Further, one consultant was asked for truth-value judgments as based on the comparison of two propositions within this context. The consultant reported that the proposition with the modal mesthine is true if the proposition with the necessity modal mesthi is true. They also reported that the proposition with the possibility modal paleng is true if the proposition with the modal mesthine is true. 
Weak necessity without weak possibility

Context:

The math teacher says: The ball is in box A or in box B or in box C. It is not in box A. It is not in box B. So ...

(adapted from von Fintel \& Gillies 2007: p.59, no. (42))

Bal-e mesthi neng $C$.

ball-DEF EPIS.NEC in $\mathrm{C}$

'The ball must be in C.'

$\leadsto$ Bal-e mesthi-ne neng $C$.

ball-DEF EPIS.NEC-NE in $\mathrm{C}$

'The ball should be in C.'

$\leadsto$ Bal-e paleng neng $C$.

ball-DEF EPIS.POS in $C$

'The ball might be in C.'

Consider next the sequence in (44), where speakers were asked to judge the acceptability of the sentences following the discourse contexts, while keeping in mind the two discourse contexts were connected. In this case, the follow-up (= the additional facts that the speaker remembers about the sandals) results in the speaker weakening her epistemic commitment to the proposition that Dur be at home. Speakers accepted the order where the first modal claim is with the strong necessity modal mesthi and the second is with the same modal plus -NE, suggesting again that the -NE weakens the strength of the necessity. Crucially, in (44d), the speaker explicitly negates the necessity claim, and doing so does not result in a contradiction. ${ }^{18}$

(44) a. Context: You see there is a light on at Yu Dur's house, and her sandals are there too. You think:

b. Yu Dur mesthi nek omah sa'iki. sister Dur EPIS.NEC at house now 'Dur must be at home now.'

c. Follow-up ('Weakening'):

But then you remember that Yu Zum has the same sandals, and she often stays over at Yu Dur's place. You think:

d. Yu Dur mesthi-ne nek omah tapi gak mesthi. sister Dur EPIS.NEC-NE at house but NEG EPIS.NEC 'Dur should be at home, but it's not a must/ not certain.'

18 Unlike its English counterpart must, mesthi can scope under negation, as shown in (44d); see also Ekowardono et al. 1999 for Standard Javanese. This point of variation between English and Javanese is also reflected in the translation of the example. 
We suggest that the negated necessity claim is in fact an implicature that the -NE-marked necessity modal gives rise to. We show in (45) that this implicature can be cancelled, and a weak necessity statement can be strengthened to strong necessity; additional examples are in (48) to (51) below. In this sequence, the first proposition is with the modal mesthine. The second is with the strong necessity modal mesthi in a context where the speaker's epistemic commitments have been strengthened.

(45) a. Context: You see there is a light on at Bu Deli's house. You think:

b. Bu Deli mesthi-ne nek omah sa'iki.

Mrs. Deli EPIS.NEC-NE at house now

'Mrs. Deli should be at home now.'

c. Follow-up ('Strengthening'):

Then you see there are Deli's sandals in front of the door. You think:

d. Bu Deli mesthi nek omah sa'iki. Mrs. Deli EPIS.NEC at house now 'Mrs. Deli must be at home now.'

Importantly, too, when the modal statements are in the opposite sequence than in (44) and (45), the respective follow-up is infelicitous: First, in the discourse context in (46a), the weak epistemic necessity modal mesthine is felicitous. However, it is not felicitous to then follow up with mesthi after weakening the speaker's epistemic commitments. In other words, the necessity modal mesthi cannot have a weaker modal claim than its -NE-marked counterpart.

(46) a. Context: You see there is a light on at Yu Dur's house, and her sandals are there too. You think:

b. Yu Dur mesthi-ne nek omah sa'iki. sister Dur EPIS.NEC-NE at house now 'Dur should be at home now.'

c. Follow-up ('Weakening'):

But then you remember that Yu Zum has the same sandals, and she often stays over at Yu Dur's place. You think:

d. \#Yu Dur mesthi nek omah. sister Dur EPIS.NEC at house ('Dur must be at home.') 
Weak necessity without weak possibility

Second, in the context set up in (47a), the epistemic necessity modal mesthi is felicitous. However, in the context of (47c) that is set up to require further strengthening, the follow-up with mesthine is judged to be unacceptable.

(47) a. Context: You see there is a light on at Bu Deli's house. You think:

b. Bu Deli mesthi nek omah sa'iki.

Mrs. Deli EPIS.NEC at house now

'Mrs. Deli must be at home now.'

c. Follow-up ('Strengthening'):

Then you see there are Deli's sandals in front of the door.

You think:

d. \#Bu Deli mesthi-ne nek omah sa'iki.

Mrs. Deli EPIS.NEC-NE at house now

('Mrs. Deli should be at home now.')

Additional examples that show that -NE-marked necessity modals like kudune and mesthine give rise to the implicature that the stronger necessity statement is false (and that this implicature can be cancelled) are in (48) to (51). Crucially, unlike in (45), the cancellation here does not rely on a follow-up context, but a correction with sa'benere 'in fact, actually' or sa'tenane 'actually, truly'. Examples (50) and (51) involve question-answer pairs, which block self-repair strategies on the part of the speaker (see also Mayol \& Castroviejo 2013).

(48) a. Context: The boss is talking to his employees.

b. Sampean kudu-ne moco petunjuk manual-e; 2 ROOT.NEC-NE AV.read safety manual-DEF

sa'bener-e sampean kudu!

SA-right-DEF 2 ROOT.NEC

'You ought to read the safety manual; actually you have to.'

(49) a. Context: Mrs. Siti took the bus at 2pm from Surabaya to Paciran. Usually the bus gets to Paciran a bit after $5 \mathrm{pm}$. Now it is $6 \mathrm{pm}$.

b. Siti mesthi-ne turun nok Paciran.

Siti EPIS.NEC-NE descend at Paciran

Sa'tenan-e, Siti mesthi turun.

SA-true-NE Siti EPIS.NEC descend

'Siti should have gotten off in Paciran.

Actually, she must have gotten off!' 
(50) Context: The student, Bambang, asks his teacher a question about the course readings. The teacher answers him.

Q: Aku kudu-ne moco buku iki toh?

ISG ROOT.NEC-NE AV.read book DEM FOC Question: 'Should I read this book?'

A: Iyo. Sa'bener-e awakmu kudu moco. yes SA-right-DEF 2 ROOT.NEC AV.read Answer: 'Yes. Actually, you have to read [it].'

(51) Context: Usually at 7am, Mrs. Deli is at home. She usually goes to work at $8 \mathrm{am}$. Now it is $7 \mathrm{am}$.

Q: Mesthi-ne Bu Deli nek omah toh? EPIS.NEC-NE Mrs. Deli at house FOC Question: 'Is it probable that Mrs. Deli is at home?'

\section{A: Sa'bener-e $\mathrm{Bu}$ Deli mesthi nek omah sa'iki.} SA-right-DEF Mrs. Deli EPIS.NEC-NE at house now Answer: 'Actually, Mrs. Deli must be at home now.'

We conclude from the discussion of the data in this section that -NE indeed has a precise role in the weakening of the strength of a necessity modal expression. In how far is it functional morphology dedicated to that purpose, though? That is, is -NE also used for counterfactual marking, as in the languages discussed in von Fintel \& Iatridou 2008? We resolve these questions in the next section.

\subsection{Not counterfactual marking}

While -NE allows us to build a weak out of a strong necessity modal, this suffix is not counterfactual (CF) marking, for distributional and morphosyntactic reasons.

Across languages, counterfactual marking occurs in two environments (see, e.g., Iatridou 2000, von Fintel \& Iatridou 2008, Romero 2017): Present and past counterfactual conditionals like (52), and present and past counterfactual wishes like (53). In both English and Spanish, counterfactuality is marked by a past tense that is not interpreted as such (and hence has also been called a fake), obligatorily in combination with subjunctive mood in Spanish. In Javanese, -NE is not obligatory in either of these environments. 
Weak necessity without weak possibility

(52) a. Si Juan tuviese resaca, estaría en la cama. -Spanishif Juan had(SUBJ) hangover is(SUBJ) in the bed

'If Juan had a hangover, he would be in bed.'

b. Si Juan hubiese ido a la fiesta, if Juan had(SUBJ) gone to the party la fiesta habría sido divertida. the party had(SUBJ) been amusing 'If Juan had gone to the party yesterday, the party would have been fun.'

(Romero 2017: p. 375, no.(3)-(4), our glosses)

(53) a. *I wish I have a car.

b. I wish I had a car.

c. I wish I had had a car.

(Iatridou 2000: p. 239, no. (25))

An example of a past CF conditional from Javanese is in (54), and examples of present CF conditionals are in (55) and (56). While we have to leave a more in-depth description of counterfactuality in Javanese for another time, the examples show that -NE is not required in this type of conditional, even though it can optionally occur on a necessity modal in the consequent, as in the first example. What appears to be necessary to form a CF conditional in Javanese is the overt presence of the prospective aspect marker ape or of some modal expression in the consequent: In (56c), the absence of mesthi renders the example infelicitous in this context; it can not receive a CF interpretation. ${ }^{19}$

(54) a. Context: Luckily, Dewi was not hit by the car!

b. Nek mobil iku wes nubruk Dewi, if car DEM already AV.hit Dewi mesti(-ne) deweke wes mati. EPIS.NEC-NE 3 already AV.die 'If that car had hit Dewi, she would have died.'

19 Once we know more about counterfactuality in Javanese, it will be worthwhile to investigate whether Javanese fits in with the languages discussed in von Fintel \& Iatridou 2008, which use CF-marking in co-occurrence with the necessity modal verb to derive weak necessity. If it turns out that Javanese does not mark CF overtly, then there is nothing more to say. If Javanese has morphosyntactic strategies to mark CF, but does not use CF-marking to derived weak modal strength, it will be important to understand why (see also Rubinstein 2014: p. 521. We thank a reviewer for discussion of this point. 
(55) a. Context: Time ran out.

b. Nek isek onok waktu, aku ape masak kolek. if still EXIST time ISG PROSP AV.cook sweet.dish 'If there were still time, I would make kolek [a dessert based on sugar, coconut milk, and pandanus leaf].'

(56) a. Context: Ely is not smart in biology and she is not a doctor.

b. Nek Ely pinter biologi, deke mesthi dadi dokter. if Ely smart biology 3 EPIS.NEC become doctor 'If Ely were smart in biology, she would certainly be a doctor.'

c. \#Nek Ely pinter biologi, deke dadi dokter. if Ely smart biology 3 become doctor (Int.) 'If Ely were smart in biology, she would be a doctor.' (Lit.) 'If Ely is smart in biology, she will become a doctor.'

Attempts of forming CF conditionals by using -NE marking on the verb in either the antecedent or the consequent of the conditional are not successful for independent reasons: Recall from Section 4.1 that $-\mathrm{NE}_{1}$ can only attach to auxiliaries and adverbs. In (57), the suffix is thus interpreted as $-\mathrm{NE}_{2}$ attaching to a nominalised verb and is thus ungrammatical. Even just in terms of its morphosyntactic distribution, -NE is thus not a good candidate for CF marking. For this reason, we also do not expect -NE to occur in the expression of CF wishes such as (58).

(57) *Nek Ely pinter biologi, deke dadi-ne dokter. if Ely smart biology 3SG become-NE doctor (Int.) 'If Ely were smart in biology, she would have become a doctor.' (Lit.) 'If Ely is smart in biology, her becoming is a doctor.'
a. Translation prompt:
b. Karep-ku aku nduwe montor. wish-my ISG AV.have car 'I wish I had a car.'

We conclude that -NE is not CF marking. The data from Javanese thus contribute a new crosslinguistic pattern in how weak necessity modality can be derived. 
Weak necessity without weak possibility

\subsection{Restriction to necessity modality}

Counterfactual morphology in languages like French can also combine with possibility modals, as in (59). In Javanese, the distribution of -NE differs in that it may not attach to possibility modals, even though they are of the right morphosyntactic category: Recall from Section 3.3 that the epistemic modals mesthi, paleng in Javanese are adverbs, while the root modals $k u d u_{1}$, iso, and oleh are auxiliaries.

(59) Je pourrais faire la vaisselle, le ménage, - French I can.Cond do the dishes the cleaning le repassage et passer l'aspirateur. the ironing and pass the.vacuum 'I could do the dishes, the cleaning, the ironing, and the vacuuming.' ${ }^{20}$

As is illustrated in (6o) to (62), the suffix -NE may not combine with any of the possibility modals to derive weak (or strong) possibility.

(6o) a. Context: Usually when Bu Dila's house light is on, it means she is home, but when she goes out she often forgets to turn it off.

b. Dila paleng nek omah. Dila EPIS.POS at home 'Dila might be at home.'

c. *Dila paleng-e nek omah.

Dila EPIS.POS-NE at home (Int.) 'There is a slight possibility Dila is at home.'

(61) a. Aku iso ngelangi.

ISG CIRC.POS AV.Swim

'I can swim.'

b. *Aku iso-ne ngelangi.

ISG CIRC.POS-NE AV.Swim

(Int.) 'There is a slight possibility that I can swim.'

(62) a. Awakmu oleh lungo kemanten-an.

2 DEON.POS go marriage-NMLZ

'You may go to the wedding.'

b. *Awakmu oleh-e lungo kemanten-an.

2 DEON.POS-NE go marriage-NMLZ

(Int.) 'There is a slight possibility that you may go to the wedding.'

20 Yoopies posting (URL: https://tinyurl.com/yoopies-post, last accessed 24th June 2020). 
As discussed in Section 2.2 above, weak possibility is also not ruled out on conceptual grounds, and it will be crucial that the semantics for -NE capture the incompatibility with possibility modals. Retracing our discussion from that section, a domain restriction approach does not predict such a distribution without further assumptions. In fact, it would predict that -NE suffixation results in strengthening with possibility modals. Degree-based approaches would not make this prediction, but also do not predict the distribution of -NE. (We will return to this discussion in Section 5.1.)

\subsection{No change in the modal flavour}

We explore in this section whether we can identify any other meaning components of -NE, apart from the weakening it induces. A morphologically induced change in modal flavour is attested in German, for instance (see Matthewson \& Truckenbrodt 2018). The data in (63) to (65) however show that the broad overall modal flavour under -NE remains constant across epistemic, deontic, and teleological modality.

The epistemic necessity modal mesthi, when modified by -NE, still only expresses epistemic modality, as in (63). It can neither receive the deontic reading that is plausible for (64), nor the teleological reading that the context in (65) sets up, which are parallel to the examples with mesthi in (37) to (39) above. The root necessity modal $k u d u_{1}$ when modified by -NE still cannot receive an epistemic reading, as illustrated in (63). Kudune may however receive a deontic reading as in (64) or a teleological reading as in (65), parallel to its root $k u d u_{1}$.

a. Context: - EPISTEMIC Commenting on the weather based on what the sky looks like.

b. \{Mesthi-ne/ \#kudu-ne\} wes terang udan-e. EPIS.NEC-NE ROOT.NEC-NE already clear rain-DEF 'It should be done raining.' (Lit.) 'The rain should have cleared.'

(64) Kowe \{kudu-ne/ \#mesthi-ne\} maca petunjuk manual-e. 2 ROOT.NEC-NE EPIS.NEC-NE AV.read safety manual-DEF 'You ought to read the safety manual.' - DEONTIC- 
Weak necessity without weak possibility

(65)

a. Context:

- TELEOLOGICAL -

If you have to go to Blimbing market, you can get there by different ways. You can take a horse-drawn carriage, machine rickshaw, a public van, or a motorbike if you have one. Patrus and Dur think the the best way to go to the Blimbing market is by horse-drawn carriage because it's more relaxing and the cheapest. So, in Patrus and Dur's opinion ...

b. Nek sampeyan reng pasar Blimbing,

if 2 to market Blimbing

\{kudu-ne/ \#mesthi-ne\} numpak dokar.

ROOT.NEC-NE EPIS.NEC-NE AV.ride horse.carriage

'If you go to Blimbing market,

you should take a horse-drawn carriage.'

An example of a potentially circumstantial interpretation of kudune is in (66), even though it is conceptually not trivial to conceive of a weak circumstantial necessity. ${ }^{21}$

(66) a. Context [offered by consultant]:

- CIRCUMSTANTIAL You really have to pee.

b. Aku kudu-ne wes nguyoh. 1SG ROOT.NEC-NE already AV.pee

'I should have peed already.'

We conclude that the affixation of -NE to necessity modals mesthi and kudu does not result in a change of their modal flavour.

\subsection{Interim summary}

Javanese encodes the weakening of a modal necessity claim with a dedicated functional morpheme, -NE. Unlike in the languages discussed by von Fintel \& Iatridou (2008) that derive weak modal strength in a morphologically transparent manner with counterfactual morphology, -NE does not mark counterfactuality. Within the modal paradigm of Javanese, its distribution is restricted to strong necessity modals. Our semantics for -NE will have to capture two empirical observations in particular: First, it will need to account for

21 It might be for that reason that the sentence only has a counterfactual interpretation. The intricacy of this example is beyond the scope of this paper. We thank one of the editors, Magdalena Kaufmann, for raising this issue. 
the weakening of the necessity claim (as witnessed in the entailment patterns that arise, and the behaviour with respect to the conjunction of mutually exclusive propositions). Second, it will also have to account for its distribution in the modal system of Javanese, and explain why -NE cannot combine with possibility modals.

\section{A semantics for Javanese -NE: Deriving weak necessity without weak possibility}

In this section, we develop an analysis for Javanese -NE that is a new variant of a domain restriction approach: While we maintain with von Fintel \& Iatridou (2008) that weak quantificational strength in Javanese is a result of quantifying over a subset of the original domain of quantification that is determined by the accessibility relation and the primary ordering source, we propose that this quantification is over a contextually provided, non-empty subset of a minimal witness set for the quantification. This analysis predicts weak necessity without weak possibility, unlike the existing analyses that we introduced in Section 2.3. We will first spell out the reasons for not adopting these approaches in Section 5.1 and then introduce our proposal in Section 5.2.

\subsection{Against previous approaches}

Problems for the standard domain restriction approach. Under domain restriction approaches to weak modal strength, weak necessity can be characterised as quantification over a subset of the domain of its strong counterpart. Under the analyses in von Fintel \& Iatridou 2008 and Rubinstein 2012, 2014, this smaller domain of quantification is a result of a secondary ordering source (see Section 2.3 for details). We could thus analyse -NE as marking the presence of a secondary ordering source, a prima facie plausible analysis. Why not, then?

Such an analysis would make wrong predictions as to the distribution of -NE, at least without any further assumptions: If -NE were indeed to flag the presence of a secondary ordering source, this option should also be available for possibility modals in Javanese, contrary to fact. In addition, as we have discussed in Section 2.3 as a concern for the analysis of English weak modal strength, a smaller quantificational domain in the case of a possibility modal results in strengthening and would thus derive what one could call an extra strong possibility modality. To address this problem, one could stipulate 
Weak necessity without weak possibility

that -NE-suffixation must result in weakening, hence its unacceptability with possibility modals, as in (67). ${ }^{22}$ It is unclear though what the status of (67) would be in the grammar of Javanese, and whether it could be derived from more general grammatical principles.

(67) Weaken, don't strengthen!

-NE is licensed only if the resulting proposition is weaker; that is, the unmodified proposition logically entails its -NE-marked counterpart.

Under such an analysis, -NE would be a close relative (or rather, the mirror image) of the English Negative Polarity Item any, for which Kadmon \& Landman (1993) suggest the strengthening requirement in (68). ${ }^{23}$

(68) Strengthening: Any is licensed only if the widening that it induces creates a stronger statement, i.e., only if the statement on the wide interpretation $\Rightarrow$ the statement on the narrow interpretation.

(Kadmon \& Landman 1993: p. 369, no. (C))

The conceptual parallels between (67) and (68) should not, however, disguise that any and -NE would be very different creatures, the former an alternativesensitive operator that interacts with exhaustification, and the latter merely a placeholder for a secondary ordering source that brings about a restriction of the domain of quantification. Deriving a requirement like (67) from more general grammatical principles would require an alternative-based semantics for -NE that is sensitive to the entailments of different quantificational operators. We do not pursue such an analysis any further in this paper. We will however adopt an analysis under which -NE suffixation results in a smaller domain of quantification, albeit through different technical means. Before spelling out the details of this analysis, we discuss the arguments against a degree-based approach to the semantics of -NE.

Against a degree-based approach to the semantics of -NE. A degree-based approach to the semantics of -NE does not seem feasible for at least two reasons: First, such an approach does not lend itself to explaining the distribution of -NE, as it does not rule out weak possibility (an advantage it has

22 We would like to thank one of our reviewers for discussion on this point.

23 This idea has been spelled out in greater technical detail more recently by Chierchia (2013) and Fox \& Spector (2018), who derive this restriction as an economy condition on the exhaustification of alternative propositions. 
over the domain restriction approach for the analysis of English). Second, unlike their English counterparts, weak necessity modals in Javanese do not participate in any of the comparison constructions of the language.

In the typology of Stassen (1985), Javanese adopts a particle comparative, in which the gradable adjective or adverb is obligatorily marked by luweh 'more'. The standard of the comparison in Javanese is introduced by timbang 'than' or teko 'from', as is illustrated in (69) to (71). We follow Vander Klok (2011) in assuming that the semantics of comparison constructions in Javanese is degree-based (for crosslinguistic variation in the grammar of comparison, see also Beck et al. 2009, Bochnak 2015, Deal \& Hohaus 2019, Hohaus \& Bochnak 2020). Following von Stechow (1984), evidence for such an analysis comes from differential comparatives like (70) and from comparison with a degree as in (71), where the standard of the comparison is a measure phrase.

(69) a. Siti *(luweh) dhuwur timbang Amina.

Siti more high than Amina

'Siti is taller than Amina.'

b. Siti mlayu luweh cepet timbang Amina.

Siti AV.run more fast than Amina

'Siti ran faster than Amina.'

(70) Fina iku rong senti luweh dhuwur timbang

Fina DEM two.LNK centimeter more high than

mbah-ne.

grandmother-DEF

'Fina is $2 \mathrm{~cm}$ taller than her grandmother.'

(71) Dayu luweh dhuwur teko sak meter setengah.

Dayu more high from one meter half

'Dayu is taller than 1.5 meters.'

Weak necessity modal adverbs are however not gradable and are unacceptable when they occur in the comparative, as we show in (72) and (73). Consultants instead offer the borrowed mending 'better' from Indonesian in (74) as an alternative to express the comparison. 
Weak necessity without weak possibility

a. \#Aku kudu-ne nggarap PR-ku luweh timbang aku ISG ROOT.NEC-NE AV.work homework-my more than ISG kudu-ne dolan mbek konco-ku. ROOT.NEC-NE hang.out with friend-my (Int.) 'I ought to work on my homework more than I ought to hang out with my friends.'

b. \#Mesthi-ne aku takok doktor-ku luweh timbang aku EPIS.NEC-NE 1SG ask doctor-my more than ISG mesthi-ne takok tonggo-ku. EPIS.NEC-NE ask neighbour-my (Int.) 'I should ask my doctor more than I should ask my neighbour.'

(73) \#Luweh kudu-ne aku nggarap PR-ku timbang dolan. more ROOT.NEC-NE 1SG AV.work homework-my than hang.out (Int.) 'It's better that I work on my homework than hangout.'

(74) Luweh mending aku nggarap PR-ku timbang dolan. more better 1SG AV.work homework-my than hang.out 'It's better that I work on my homework than hangout.'

The ungrammaticality of weak necessity modal adverbials in the comparative suggests that they do not have an underlying degree-based semantics.

\subsection{Our proposal}

Javanese -NE is used to weaken modal strength, but is sensitive to the distinction between possibility and necessity, which translates to existential and universal quantification over the favoured worlds under the standard quantificational analysis of modality. How can we capture these properties of -NE? We suggest here a different type of domain restriction analysis: We propose that Javanese -NE weakens a necessity modal expression by requiring that the prejacent be true throughout a non-empty subset of those worlds that would have to make the prejacent true in order for the strong necessity modal statement to hold.

The proposal additionally exploits a distinction between existential and universal quantification when it comes to the sets that make the quantification true: For a strong necessity statement to be true, the prejacent has to be true in all of the favoured worlds. We can characterise those worlds, the worlds minimally required to vouchsafe for the truth of the overall modal 
claim as the truthmakers or witnesses. We suggest that -NE relies on this notion of witnesses, or more specifically of minimal witness sets (see also Barwise \& Cooper 1981, Szabolcsi 1997, Endriss \& Hinterwimmer 2009), as defined in (75).

(75) A set $W$ is a minimal witness set WIT for a generalised quantifier $G$ if and only if $W \in G$, and there is no set $W^{\prime} \subset W$ such that $W^{\prime} \in G$.

Applied to an example from nominal quantification, the minimal witness set for every lawyer (assuming no further contextual domain restriction) is $\llbracket$ lawyer , the set of all lawyers. For three lawyers, any set with cardinality three where each of the members is a lawyer qualifies as a minimal witness set. For some lawyer, any singleton set that contains an individual that is a lawyer qualifies as such a witness set. Minimal witness sets for existential quantification under this definition are thus singleton sets, a feature which we will exploit (together with the subset requirement) to explain why -NE cannot combine with possibility modals: Their minimal witness sets are singleton sets which don't have any non-empty (proper) subsets. We implement this idea more formally in (76).

(76) For any $W \in D_{\langle s, t\rangle}$, any $G \in D_{\langle\langle s, t\rangle, t\rangle}$, and any $p \in D_{\langle s, t\rangle}$ :

$\llbracket-\mathrm{NE} \rrbracket(W)(G)(p)$ is defined iff $W \neq \varnothing \& \exists W^{\prime}\left[W^{\prime} \in \mathrm{WIT}(G) \& W \subset W^{\prime}\right]$. $\llbracket-\mathrm{NE} \rrbracket(W)(G)(p)=1$ iff $\forall w \in W: p(w)=1$.

Under this analysis, the sentence from (45), repeated below, is interpreted on the basis of the Logical Form sketched in (77a), where the first argument of -NE is a set of worlds that is contextually supplied but depends on the world of evaluation. ${ }^{24}$ These are the worlds upon which -NE adds a definedness condition, but ultimately also the worlds which will have to make the prejacent true for the sentence to be true. The resulting interpretation of the example is in (77b).

(45) $\mathrm{Bu}$ Deli mesthi-ne nek omah sa'iki. Mrs. Deli EPIS.NEC-NE at house now 'Mrs. Deli should be at home now.'

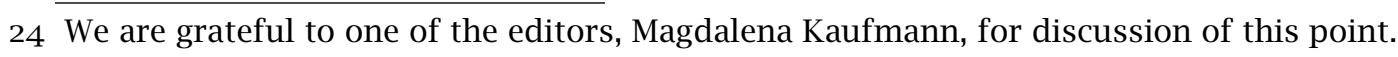


Weak necessity without weak possibility

(77) Logical Form and interpretation:

a.

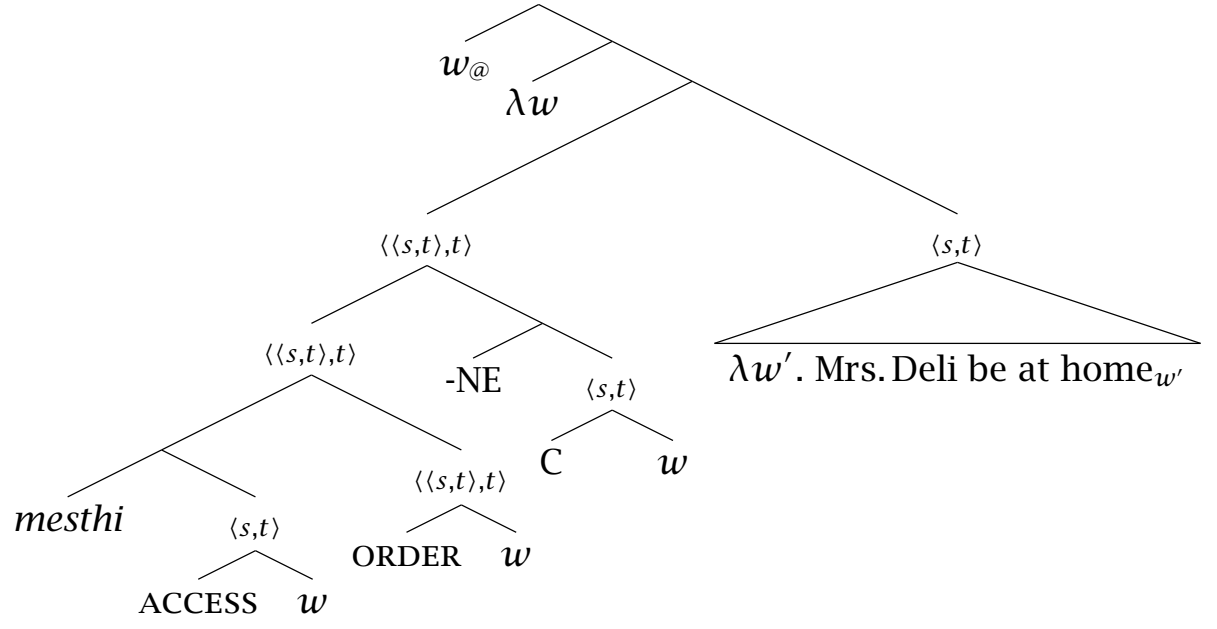

b. $\quad \llbracket-\mathrm{NE} \rrbracket\left(\mathrm{C}_{w_{@}}\right)\left(\llbracket\right.$ mesthi $\left.\rrbracket\left(\operatorname{ACCESS}_{w_{\circledast}}\right)\left(\operatorname{ORDER}_{w_{\circledast}}\right)\right)$

( $\left[\lambda w^{\prime}\right.$. Mrs. Deli be at home in $\left.\left.w^{\prime}\right]\right)$ is defined iff $\mathrm{C}_{w_{@}} \neq \varnothing$

$\& \exists W\left[W \in \mathrm{WIT}\left(\llbracket\right.\right.$ mesthi $\left.\left.\rrbracket\left(\operatorname{ACCESS}_{w_{@}}\right)\left(\operatorname{ORDER}_{w_{\circledast}}\right)\right) \& C_{w_{\circledast}} \subset W\right]$

$\llbracket-\mathrm{NE} \rrbracket\left(\mathrm{C}_{w_{@}}\right)\left(\llbracket\right.$ mesthi $\left.\rrbracket\left(\mathrm{ACCESS}_{w_{@}}\right)\left(\operatorname{ORDER}_{w_{@}}\right)\right)$

$\left(\left[\lambda w^{\prime}\right.\right.$. Mrs. Deli be at home in $\left.\left.w^{\prime}\right]\right)=1$

iff $\forall w \in \mathrm{C}_{w_{@}}$ : Mrs. Deli be at home in $w$

For the sentence to be true, all of the worlds in some non-empty proper subset of the favoured worlds that is accessible from the actual world will have to be such that Mrs. Deli is at home in those worlds. These truth conditions do not prevent the stronger necessity claim from being true, namely that the prejacent is true in all of the favoured worlds. This is a welcome result, as it allows for a weak necessity to be strengthened to a strong necessity, in line with the data we presented in Section 4. Standardly, as we saw, there will be an implicature to the exclusion of the strong necessity case. If the prejacent had been true in all of the favoured worlds, the speaker would have used mesthi. Strengthening a weak to a strong necessity cancels this implicature.

The analysis captures the two properties of -NE that have featured most prominently so far: It accounts for the weakening in modal strength but crucially also predicts the incompatibility of -NE with possibility modals. In the case of our example in (45), for there to be a possibility of the prejacent being true, we need at least one world that would make it so. Under the semantics for -NE in (76), the interpretation of the sentence will not be defined, and hence unacceptable: It is not possible to find a non-empty set of worlds 
that is a proper subset of the minimal witness set for existential quantification. Possibility modals do not make available any subset alternatives to their minimal witness sets. Hence, -NE cannot be used to weaken the strength of a possibility claim..$^{25}$ As is, the semantics of -NE does not say anything about the nature of the subset that weak necessity modals in Javanese quantify over.

The nature of the domain restriction. How can we characterise the properties of $W$ beyond its relation to the original domain of quantification (and thus beyond being a subset of a witness set for the quantification)? Ultimately, we do not think that the data from Javanese offer new insight into this question, even though it will be important to identify the relevant constraints. ${ }^{26}$ As discussed in Section 2.2, English weak necessity modals have been suggested to reflect an additional requirement on the favoured worlds that is sensitive to commitment (Jones \& Pörn 1986, Rubinstein 2012, 2014, Portner \& Rubinstein 2016, Silk 2019). Under this analysis, the smaller domain of quantification derives from taking into account propositions in the common ground that are considered to be negotiable. The question therefore arises whether commitment could also play a role in determining the smaller domain of quantification for -NE-marked modals in Javanese. While this is a very subtle question to investigate in the fieldwork setting, the very least we can say is that -NE is compatible with contexts where the weakening

25 This behaviour is reminiscent of the behaviour of English almost (Sigrid Beck, p.c.). As illustrated in (i), almost can modify the universal quantificational determiner every, but not its existential counterpart some (see also, among others, Ladusaw 1979, Carlson 1981, Partee 1986, Kadmon \& Landman 1993). What is intuitively amiss in (ib) is that either we are talking about one lawyer or no lawyer (there's no in-between), an intuition that we can extend to the weak possibility case.

(i) a. Almost every lawyer could answer that question.

b. \#Almost some lawyer could answer that question.

(Kadmon \& Landman 1993: p. 354, no. (13), (15))

A full comparison between English almost and Javanese -NE is beyond the scope of this paper, but a potentially interesting venue for future research would be to explore whether the two belong to the same family of operators and share other properties.

26 We would like to thank our reviewers and one of the editors, Magdalena Kaufmann, for discussion of this point (and in particular of the role of commitment in the case of epistemic weak necessity). 
Weak necessity without weak possibility

of a root or epistemic necessity claim is plausibly related to the negotiability of the propositions that determine the worlds under consideration.

A relevant root modality example is in (78). While it is a tradition that the firstborn marries first, it is not always adhered to in modern Javanese society, even in Paciran village. Using the -NE-marked modal plausibly flags this variable commitment to the tradition. (79) replicates a set of key examples from Rubinstein (2012), where the context manipulates how important health insurance might be considered. While both strong necessity kudu and weak necessity modal kudune are acceptable in (79a), the strong necessity modal is infelicitous in (79b).

(78) a. Context: Waiq is the firstborn child, and he has not married yet. His younger brother, Hakim, wants to marry. But according to Javanese tradition, ...

b. Sing mbarep kudu-ne kawin dhisek.

REL firstborn ROOT.NEC-NE marry first

'The firstborn ought to marry first.'

(79) a. Context: Miss Mayu is coming to Canada next year. It is now illegal not to have health insurance. Miss Mayu will study English at McGill University.

Deke $\{k u d u / \quad k u d u-n e\} \quad n d u w e$ asuransi kesehatan. 3 ROOT.NEC ROOT.NEC-NE AV.have insurance health 'She has to/should have health insurance.'

b. Context: Miss Mayu is coming to Canada next year. It is now illegal not to have health insurance. Miss Mayu will be employed illegally as a nanny because the family will not provide the right kind of visa.

Deke $\left\{{ }^{\# k u d u / \quad k u d u-n e\} \quad n d u w e ~ a s u r a n s i ~ k e s e h a t a n . ~}\right.$ 3 ROOT.NEC ROOT.NEC-NE AV.have insurance health 'She should have health insurance.'

Two relevant examples of epistemic weak necessity in Javanese that are compatible with commitment (or lack thereof) driving the smaller domain of quantification are in (44) and (63), repeated below. Here, the speaker plausibly flags that they are uncertain as to whom the sandals belong to or as to the assumptions that they have based their personal weather forecast on. 
(44) a. Context: You see there is a light on at Yu Dur's house, and her sandals are there too. You think:

b. Yu Dur mesthi nekomah sa'iki. sister Dur EPIS.NEC at house now 'Dur must be at home now.'

c. Follow-up ('Weakening'):

But then you remember that Yu Zum has the same sandals, and she often stays over at Yu Dur's place. You think:

d. Yu Dur mesthi-ne nek omah tapi gak mesthi. sister Dur EPIS.NEC-NE at house but NEG EPIS.NEC 'Dur should be at home, but it's not a must/ not certain.'

(63) a. Context: Commenting on the weather based on what the sky looks like.

b. Mesthi-ne wes terang udan-e. EPIS.NEC-NE already clear rain-DEF 'It should be done raining.'

We leave a more detailed exploration of the types of subsets that Javanese -NE can select to further research. Let us point out though that our proposed analysis is in principle amenable to a refinement that builds commitment (or lack thereof) into the semantics of -NE as a presupposition on the value of its first argument.

\section{Conclusion}

In this paper, we identified affixation by -NE as the morphological strategy by which Javanese derives weak necessity modal expressions from their strong counterparts, regardless of whether they express root or epistemic modal flavour. In light of the crosslinguistic data discussed in von Fintel \& Iatridou 2008, we argued that -NE does not serve double duty as counterfactual morphology.

When it comes to weak necessity, Javanese compositionally manipulates modal strength through an operator, repeated in (76), that quantifies over a proper non-empty subset of a minimal witness set for the modal quantification. In the necessity case, quantification will thus be over a proper subset over the favoured worlds (by the definition of what it means to be a minimal witness set). 
Weak necessity without weak possibility

(76) For any $W \in D_{\langle s, t\rangle}$, any $G \in D_{\langle\langle s, t\rangle, t\rangle}$, and any $p \in D_{\langle s, t\rangle}$ :

$\llbracket$-NE $\rrbracket(W)(G)(p)$ is defined iff $W \neq \varnothing \& \exists W^{\prime}\left[W^{\prime} \in \mathrm{WIT}(G) \& W \subset W^{\prime}\right]$.

$\llbracket$-NE $\rrbracket(W)(G)(p)=1$ iff $\forall w \in W: p(w)=1$.

The resulting truth conditions for weak necessity modality under this account are equivalent to the truth conditions that domain restriction approaches derive, but are arrived at in a different compositional manner. Possibility modal expressions are not amenable to such a quantification, as they lack the right kind of subsets. Informally speaking, possibility is already so weak a quantificational notion that it cannot be weakened.

\section{Directions for further research}

The paper is programmatic in that it opens up two directions for future research, one within Austronesian linguistics (Section 7.1) and one regarding the crosslinguistic typology of weak necessity (Section 7.2).

\subsection{Within Malayo-Polynesian linguistics}

Further research will have to show whether the morphological strategy identified here for Javanese, with its restriction to necessity modality, is found in other languages within and beyond the Austronesian language family.

Within Austronesian, this strategy seems to potentially also be in use in other languages within the Western Malayo-Polynesian branch: A relevant example from Indonesian is in (80), where the necessity modal harus is affixed with se- and -nya, a morphological strategy that is also attested with se-mesti-nya 'should, ought to' (Sneddon 2010: p. 371).

Saya se-harus-nya berangkat tanggal dua. - Indonesian ISG as-NEC-NYA leave date two 'I should have left on the second.'

(Sneddon 2010: p. 371, glosses by the first author)

A similar form can be found in Standard Javanese sa-mesthi-ne 'as it should be' (Robson \& Wibisono 2002), and in number of other languages, including Balinese (se-)patut-ne 'ought' (Ari Natarina, p.c.), Madurese sa-onggu-na 'apparently' with the root onggu an epistemic modal (Davies 2010: pp. 393-394), and Sundanese sa-kudu-na 'ought' (Eri Kurniawan, p.c.). If these modal ex- 
pressions meet the definition for weak necessity, the question arises as to whether we can identify a distinct semantic contribution of the prefix se-/ sa-.

Another venue for further research is the use of -NE in the nominal domain within Javanese, identified as $-\mathrm{NE}_{2}$ in Section 4.1, and its counterpart in many related languages, descriptively characterised as marking definiteness in Javanese, Madurese, and Indonesian (Davies \& Dresser 2005, Davies 2010, Sneddon 2010). An example of this use in Javanese is in (40); other examples throughout the paper include (2), (35), (36), (43), (63), and (64).

(40) Kucing-e $e_{2}$ nyolong iwak.

cat-DEF AV.steal fish

'The cat stole some fish.'

(Davies \& Dresser 2005: p. 61)

The question arises whether a uniform semantic analysis of the two suffixes is empirically warranted and possible, or at least an analysis under which $-\mathrm{NE}_{1}$ and $-\mathrm{NE}_{2}$ are systematically related. Does $-\mathrm{NE}_{2}$ indeed encode definiteness in the same way than it is usually assumed for English the in (81), presupposing existence and uniqueness? Would the data also be compatible with a domain-restriction analysis?

$$
\llbracket \text { the } \rrbracket=\lambda p: p \in D_{\langle e, t\rangle} \& \exists ! x[p(x)=1] . \iota x[p(x)=1]
$$

If related either synchronically or diachronically, we could characterise Javanese as borrowing from the nominal domain to weaken modal strength rather than using CF marking, thus contributing to our understanding of the crosslinguistic picture of graded modality and modal strength distinctions.

\subsection{The typology of weak necessity}

Concerning the crosslinguistic picture, our analysis of Javanese and the discussion in the research literature suggests that weak modal strength is not a uniform phenomenon across languages, neither lexico-morphologically nor semantically. Concerning form, weak modal strength can be lexicalised or derived in a morphologically more transparent way, and these two strategies appear to not be mutually exclusive within a language. We have identified in this paper a new type of morphologically transparent strategy: Javanese employs a dedicated functional morpheme to derive weak modal strength which is not counterfactual morphology. 
Weak necessity without weak possibility

These differences in form aside, our paper raises questions as to potential differences in the underlying composition and interpretation of modal strength distinctions. Further in-depth analyses of weak modal strength across languages are needed to identify the compositional strategies by which languages manipulate modal strength and how they relate to other properties of the grammar of modality and beyond. In particular, do the properties of weak necessity modality in Javanese that distinguish them from English form a typologically significant cluster? Such a cluster could include a lack of gradability of modal expressions, a lack of dedicated counterfactual morphology and the incompatibility with possibility modal expressions. ${ }^{27}$ Concerning the latter, Javanese raises interesting questions with regard to weak modal strength across the divide between necessity and possibility. Do languages prioritise weak necessity over weak possibility? Is there evidence for weak possibility modality in English, as we have tentatively assumed in this paper, or does the absence of weak possibility constitute a crosslinguistically stable gap in the paradigm of modal strength?

\section{Abbreviations used in glosses}

$1=$ first person, $2=$ second person, $3=$ third person, $\mathrm{APPL}=$ applicative, $\mathrm{AV}=$ actor voice, $\mathrm{CIRC}=$ circumstantial modality, $\mathrm{CL}=$ clitic, $\mathrm{CF}=$ counterfactual, $\mathrm{COND}=$ conditional mood, $\mathrm{DEF}=$ definiteness marker, $\mathrm{DEM}=$ demonstrative, $\mathrm{DEON}=$ deontic modality, EPIS $=$ epistemic modality, FOC $=$ focus, INF $=$ infinitive, INT $=$ intensifier, LNK = linker, $\mathrm{M}=$ masculine, $\mathrm{NEC}=$ necessity modal force, $\mathrm{NEG}=$ negation, $\mathrm{NMLZ}$ $=$ nominaliser, POS $=$ possibility modal force, PRES $=$ present, PROG $=$ progressive, $\mathrm{PROSP}=$ prospective aspect, $\mathrm{PRT}=$ particle, $\mathrm{PST}=$ past, $\mathrm{RED}=$ reduplication, $\mathrm{REL}=$ relativiser, $\mathrm{SG}=$ singular, and $\mathrm{SUBJ}=$ subject.

\section{References}

Barwise, Jon \& Robin Cooper. 1981. Generalized quantifiers and natural language. Linguistics and Philosophy 4(2). 159-219. https://doi.org/10.1007 /BFoo350139.

Beck, Sigrid. 2011. Comparison constructions. In Claudia Maienborn, Klaus von Heusinger \& Paul H. Portner (eds.), Semantics: An international handbook of natural language meaning, vol. 2, 1341-1389. Berlin: De Gruyter.

27 We would like to thank a reviewer for this suggestion. 
Jozina Vander Klok, Vera Hohaus

Beck, Sigrid, Svetlana Krasikova, Daniel Fleischer, Remus Gergel, Stefan Hofstetter, Christiane Savelsberg, John Vanderelst \& Elisabeth Villalta. 2009. Crosslinguistic variation in comparison constructions. Linguistic Variation Yearbook 9. 1-66. https://doi.org/10.1075/livy.9.o1bec.

Bochnak, M. Ryan. 2015. Variable force modality in Washo. North Eastern Linguistic Society (NELS) 45. 105-114.

Burton, Strang \& Lisa Matthewson. 2015. Targeted construction storyboards in semantic fieldwork. In Ryan Bochnak \& Lisa Matthewson (eds.), Methodologies in semantic fieldwork, 135-156. Oxford: Oxford University Press. $\mathrm{h}$ ttps://doi.org/10.1093/acprof:oso/9780190212339.003.0006.

Carlson, Greg N. 1981. On the distribution of free-choice any. Chicago Linguistics Society (CLS) 17. 8-23.

Chierchia, Gennaro. 2013. Logic in grammar: Polarity, free choice, and intervention. Oxford: Oxford University Press. https://doi.org/10.1093/acpro f:oso/9780199697977.001.00o1.

Conners, Thomas J. 2008. Tengger Javanese. New Haven, CT: Yale University dissertation.

Copley, Bridget. 2004. So-called epistemic should. Snippets 9(2). 7-8.

Davies, William D. 2010. A grammar of Madurese. Berlin: de Gruyter. https: //doi.org/10.1515/9783110224443.

Davies, William D. \& Craig A. Dresser. 2005. The structure of Javanese and Madurese determiner phrases. Austronesian Formal Linguistics Association (AFLA) 23. 57-73.

Deal, Amy Rose. 2011. Modals without scales. Language 87(3). 559-585. http s://doi.org/10.1353/lan.2011.006o.

Deal, Amy Rose \& Vera Hohaus. 2019. Vague predicates, crisp judgments. Sinn und Bedeutung (SuB) 23. 347-364. https://doi.org/10.18148/sub/20 19.v23i1.537.

Ekowardono, B. Karno, Suprapti, Bambang Hartono \& Setyono. 1999. Modalitas dalam bahasa jawa [Modality in Javanese]. Jakarta: Pusat Perkembangan dan Pembangunan Bahasa.

Endriss, Cornelia \& Stefan Hinterwimmer. 2009. Indefinites as direct and indirect aboutness topics. In Malte Zimmermann \& Caroline Féry (eds.), Information structure: Theoretical, typological, and experimental perspectives, 89-115. Oxford: Oxford University Press.

Errington, Joseph J. 1998. Shifting languages: Interaction and identity in Javanese Indonesia. Cambridge: Cambridge University Press. 
Weak necessity without weak possibility

Finlay, Stephen. 2009. Oughts and ends. Philosophical Studies 143(3). 315-340. https://doi.org/10.1007/s11098-008-9202-8.

Finlay, Stephen. 2010. What ought probably means, and why you can't detach it. Synthese 177(1). 67-89. https://doi.org/10.1007/s11229-009-9640-7.

von Fintel, Kai \& Anthony S. Gillies. 2007. An opinionated guide to epistemic modality. In Tamar Szabó Gendler \& John Hawthorne (eds.), Oxford studies in epistemology, vol. 2, 32-62. Oxford: Oxford University Press.

von Fintel, Kai \& Irene Heim. 2011. Intensional semantics. Lecture notes, Spring 2011. Cambridge: Massachusetts Institute of Technology. https: //github.com/fintelkai/fintel-heim-intensional-notes/blob/master/finte l-heim-2011-intensional.pdf.

von Fintel, Kai \& Sabine Iatridou. 2008. How to say ought in foreign: The composition of weak necessity modals. In Jacqueline Guéron \& Jacqueline Lecarme (eds.), Time and modality (Studies in Natural Language and Linguistic Theory (SNLT) 75), 115-141. Berlin: Springer. https://doi.org/1 0.1007/978-1-4020-8354-9_6.

von Fintel, Kai \& Lisa Matthewson. 2008. Universals in semantics. The Linguistic Review 25(1-2). 139-201. https://doi.org/10.1515/TLIR.2008.004.

Fox, Danny \& Benjamin Spector. 2018. Economy and embedded exhaustification. Natural Language Semantics 26(1). 1-50. https://doi.org/10.1007/s 11050-017-9139-6.

Fults, Scott. 2006. The structure of comparison: An investigation of gradable adjectives. College Park: University of Maryland dissertation.

Hacquard, Valentine. 2011. Modality. In Claudia Maienborn, Klaus von Heusinger \& Paul Portner (eds.), Semantics: An international handbook of natural language meaning, 1484-1515. Berlin: De Gruyter.

Hatley, Ron. 1984. Mapping cultural regions of Java. In Ron Hatley, Jim Schiller, Anton Lucas \& Barbara Martin-Schiller (eds.), Other Javas: Away from the Kraton, 1-32. Clayton: Monash University Publishing.

Heim, Irene. 2001. Degree operators and scope. In Caroline Féry \& Wolfgang Sternefeld (eds.), Audiatur vox sapientiae: A Festschrift for Arnim von Stechow, 214-239. Berlin: Akademie-Verlag.

Herburger, Elena \& Aynat Rubinstein. 2014. Is more possible more possible in German? Semantics and Linguistic Theory (SALT) 24. 555-576. https://do i.org/10.3765/salt.v24io.2717.

Herburger, Elena \& Aynat Rubinstein. 2019. Gradable possibility and epistemic comparison. Journal of Semantics 36(1). 165-191. https://doi.org/h ttps://doi.org/10.1093/jos/ffyo16. 
Hohaus, Vera. 2021. Gradability and modality: A case study from Samoan. In Lauren Clemens \& Diane Massam (eds.), Polynesian syntax and its interfaces, 11-35. Oxford: Oxford University Press. https://doi.org/10.1093/o so/9780198860839.003.0002.

Hohaus, Vera \& M. Ryan Bochnak. 2020. The grammar of degree: Gradability across languages. Annual Review of Linguistics 6. 235-259. https://doi.or g/10.1146/annurev-linguistics-011718-012009.

Horn, Laurence R. 1972. On the semantic properties of logical operators in English. Los Angeles: University of California dissertation.

Iatridou, Sabine. 2000. The grammatical ingredients of counterfactuality. Linguistic Inquiry 31(2). 231-270. https://doi.org/10.1162/002438900554352.

Jones, Andrew J. \& Ingmar Pörn. 1986. Ought and Must. Synthese 66(1). 8993. https://doi.org/10.1007/BFoo413581.

Kadmon, Nirit \& Fred Landman. 1993. Any. Linguistics and Philosophy 16(4). 353-422. https://doi.org/10.1007/BFoo985272.

Kaufmann, Stefan. 2017. The limit assumption. Semantics and Pragmatics 10(18). 1-29. https://doi.org/10.3765/sp.10.18.

Kennedy, Christopher. 1997. Projecting the adjective: The syntax and semantics of gradability and comparison. Santa Cruz: University of California dissertation.

Kennedy, Christopher. 2007. Vagueness and grammar: The semantics of absolute and relative gradable adjectives. Linguistics and Philosophy 30(1). 1-45. https://doi.org/10.1007/s10988-006-9008-0.

Keshet, Ezra. 2008. Good intensions: Paving two roads to a theory of the DeRe/ De-Dicto distinction. Cambridge: Massachusetts Institute of Technology dissertation.

Klecha, Peter. 2014. Bridging the devide: Scalarity and modality. Chicago: University of Chicago dissertation.

Kolodny, Niko \& John MacFarlane. 2010. Ifs and oughts. Journal of Philosophy 107(3). 115-143. http://www.jstor.org/stable/25700490.

Kratzer, Angelika. 1977. What must and can must and can mean. Linguistics and Philosophy 1(5). 337-355. https://doi.org/10.1007/BFoo353453.

Kratzer, Angelika. 1978. Semantik der Rede: Kontexttheorie, Modalwörter, Konditionalsätze [The semantics of speech: Context theory, modal expressions, conditional sentences]. Königstein: Scriptor.

Kratzer, Angelika. 1981. The notional category of modality. In Hans-Jürgen Eikmeyer \& Hannes Rieser (eds.), Words, worlds, and contexts: New approaches in word semantics, 38-74. Berlin: De Gruyter. 
Weak necessity without weak possibility

Kratzer, Angelika. 1991. Modality. In Arnim von Stechow \& Dieter Wunderlich (eds.), Semantik: Ein internationales Handbuch der zeitgenössischen Forschung, 639-650. Berlin: De Gruyter. https://doi.org/10.1515/9783110 126969.7 .639$.

Kusumoto, Kiyomi. 1999. Tense in embedded context. Amherst: University of Massachusetts at Amherst dissertation.

Kusumoto, Kiyomi. 2005. On the quantification over times in natural language. Natural Language Semantics 13(4). 317-357. https://doi.org/10.10 07/s11050-005-4537-6.

Ladusaw, William A. 1979. Polarity sensitivity as inherent scope relations. Austin: University of Texas dissertation.

Lassiter, Daniel. 2011. Measurement and modality: The scalar basis of modal semantics. New York City: New York University dissertation.

Lassiter, Daniel. 2017. Graded modality: Qualitative and quantitative perspectives. Oxford: Oxford University Press. https://doi.org/10.1093/oso/978 0198701347.001.0001.

Lewis, David. 1973. Causation. Journal of Philosophy 70(17). 556-567. https: //doi.org/10.2307/2025310.

Lewis, David. 1981. Ordering semantics and premise semantics for counterfactuals. Journal of Philosophical Logic 10(2). 217-234. https://doi.org/10 .1007/BFoo248850.

Matthewson, Lisa. 2004. On the methodology of semantic fieldwork. International Journal of American Linguistics 70(4). 369-451. https://doi.org/ht tps://doi.org/10.1086/429207.

Matthewson, Lisa. 2011. Methods in crosslinguistic formal semantics. In Claudia Maienborn, Klaus von Heusinger \& Paul H. Portner (eds.), Semantics: An international handbook of natural language meaning, vol. 1, 268-284. Berlin: De Gruyter.

Matthewson, Lisa. 2013. Gitksan modals. International Journal of American Linguistics 79(3). 349-394. https://doi.org/10.1086/670751.

Matthewson, Lisa. 2016. Modality. In Maria Aloni \& Paul Dekker (eds.), Cambridge handbook of formal semantics, 726-775. Cambridge: Cambridge University Press.

Matthewson, Lisa \& Hubert Truckenbrodt. 2018. Modal flavour/ modal force interactions in German: Soll, sollte, muss and müsste. Linguistische Berichte 255. 259-313. 
Jozina Vander Klok, Vera Hohaus

Mayol, Laia \& Elena Castroviejo. 2013. How to cancel an implicature. Journal of Pragmatics 50(1). 84-104. https://doi.org/10.1016/j.pragma.2013.02.0 02.

McNamara, Paul. 1996. Must I do what I ought (or will the least I can do do)? In Mark Brown \& José Carmo (eds.), Deontic logic, agency and normative systems, 154-173. Berlin: Springer. https://doi.org/10.1007/978-1-4471-1 488-8_9.

Narrog, Heiko. 2012. Modality, subjectivity, and semantic change: A crosslinguistic perspective. Oxford: Oxford University Press. https://doi.org /10.1093/acprof:oso/9780199694372.001.00o1.

Ninan, Dilip. 2005. Two puzzles about deontic necessity. In Jon Gajewski, Valentine Hacquard, Bernard Nickel \& Seth Yalcin (eds.), New work on modality, 149-178. Cambridge: MIT Working Papers in Linguistics.

Nothofer, Bernd. 1981. Dialektatlas von Zentral-Java [Atlas of the dialects of Central Java]. Wiesbaden: Harrassowitz.

Partee, Barbara H. 1986. Noun phrase interpretation and type-shifting principles. In Jeroen Groenendijk, Dick de Jongh \& Martin Stokhof (eds.), Studies in Discourse Representation Theory and the theory of generalized quantifiers, 115-143. Dordrecht: Foris. https://doi.org/10.1515/9783112420027006.

Percus, Orin. 2000. Constraints on some other variables in syntax. Natural Language Semantics 8(3). 173-229. https://doi.org/10.1023/A:101129852 6791.

Peterson, Tyler Roy Gösta. 2010. Epistemic modality and evidentiality in Gitksan at the semantics-pragmatics interface. Vancouver: University of British Columbia dissertation.

Poedjosoedarmo, Soepomo. 1968. Javanese speech levels. Indonesia 6. 54-81. https://doi.org/10.2307/3350711.

Portner, Paul. 2009. Modality. Oxford: Oxford University Press.

Portner, Paul \& Aynat Rubinstein. 2016. Extreme and non-extreme deontic modals. In Nate Charlow \& Matthew Chrisman (eds.), Deontic modality, 256-282. Oxford: Oxford University Press. https://doi.org/10.1093/acpr of:oso/9780198717928.003.0010.

Ravindranath, Maya \& Abigail C. Cohn. 2014. Can a language with millions of speakers be endangered? Journal of the Southeast Asian Linguistics Society 7. 64-75. https://doi.org/1885/11968.

Rivière, Claude. 1981. Is should a weaker must? Journal of Linguistics 17(2). 179-195. https://doi.org/10.1017/Soo22226700006940. 
Weak necessity without weak possibility

Robson, Stuart. 2014. Javanese grammar for students: A graded introduction. 2nd edn. Clayton: Monash University Publishing.

Robson, Stuart \& Singgih Wibisono. 2002. Javanese-English dictionary. Tuttle Publishing: North Clarendon.

Romero, Maribel. 2017. Tense and mood in counterfactual conditionals: The view from Spanish. Amsterdam Colloquium 21. 375-384.

Rubinstein, Aynat. 2012. Roots of modality. Amherst: University of Massachusetts at Amherst dissertation.

Rubinstein, Aynat. 2014. On necessity and comparison. Pacific Philosophical Quarterly 95(4). 512-554. https://doi.org/10.1111/papq.12047.

Rubinstein, Aynat. 2020. Weak necessity. In Daniel Gutzmann, Lisa Matthewson, Cécile Meier, Hotze Rullmann \& T. Ede Zimmermann (eds.), The Wiley Blackwell companion to semantics, vol. 4, 1-44. New York: Wiley-Blackwell. https://doi.org/10.1002/9781118788516.sem105.

Rullmann, Hotze, Lisa Matthewson \& Henry Davis. 2008. Modals as distributive indefinites. Natural Language Semantics 16(4). 317-357. https://doi .org/10.1007/s11050-008-9036-0.

Sæbø, Kjell J. 2001. Necessary conditions in natural language. In Caroline Féry \& Wolfgang Sternefeld (eds.), Audiatur vox sapientiae: A Festschrift for Arnim von Stechow, 427-449. Berlin: Akademie Verlag. https://doi.or g/10.1515/9783050080116.427.

Silk, Alex. 2019. Weak and strong necessity modals: On linguistic means of expressing a primitive concept ought. Manuscript, The University of Birmingham.

Sloman, Aaron. 1970. Ought and Better. Mind 75(315). 385-394. https://doi.o rg/10.1093/mind/LXXIX.315.385.

Smith-Hefner, Nancy. 1989. A social history of language change in Highland East Java. Journal of Asian Studies 48(2). 257-271. https://doi.org/10.230 $7 / 2057377$.

Sneddon, James N. 2010. Indonesian: A comprehensive grammar. London: Routledge.

Solt, Stephanie. 2015. Measurement scales in natural language. Language and Linguistics Compass 9(1). 14-32. https://doi.org/10.1111/lnc3.12101.

Stalnaker, Robert. 1984. Inquiry. Cambridge: Cambridge University Press.

Stassen, Leon. 1985. Comparison and universal grammar. Oxford: Basil Blackwell.

von Stechow, Arnim. 1984. Comparing semantic theories of comparison. Journal of Semantics 3(1-2). 1-77. https://doi.org/10.1093/jos/3.1-2.1. 
von Stechow, Arnim. 2009. The temporal degree adjectives früh(er) 'early(er)'/ spät(er) 'late(r)' and the semantics of the positive. In Anastasia Giannakidou \& Monika Rathert (eds.), Quantification, definiteness and nominalization, 214-233. Oxford: Oxford University Press.

von Stechow, Arnim \& Sigrid Beck. 2015. Events, times, and worlds: An LF architecture. In Christian Fortmann, Anja Lübbe \& Irene Rapp (eds.), Situationsargumente im Nominalbereich, 13-46. Tübingen: Niemeyer Verlag. https://doi.org/10.1515/9783110432893-002.

Swanson, Eric. 2008. Modality in language. Philosophy Compass 3. 1193-1207. https://doi.org/10.1111/j.1747-9991.2008.00177.x.

Szabolcsi, Anna. 1997. Background notions in lattice theory and generalized quantifiers. In Anna Szabolcsi (ed.), Ways of scope taking (Studies in Linguistics and Philosophy (SLAP) 65), 1-27. Berlin: Springer. https://doi.org /10.1007/978-94-011-5814-5_1.

Vander Klok, Jozina. 2011. Indirect modification in Javanese: Evidence from attributive comparatives. Chicago Linguistic Society (CLS) 45. 625-639.

Vander Klok, Jozina. 2012. Tense, aspect, and modal markers in Paciran Javanese. Montréal: McGill University dissertation.

Vander Klok, Jozina. 2013. Pure possibility and pure necessity modals in Paciran Javanese. Oceanic Linguistics 52(2). 346-378. http://www.jstor.org/st able/43286355.

Vander Klok, Jozina. 2019. The Javanese language at risk: Perspectives from an East Java village. Language Documentation and Conservation 13. 300345. https://doi.org/10125/24868.

Villalta, Elisabeth. 2008. Modality and gradability: An investigation of the subjunctive mood in Spanish. Linguistics and Philosophy 31(4). 467-522. https://doi.org/10.1007/s10988-008-9046-x.

Wedgwood, Ralph. 2006. The meaning of ought. In Russ Shafer-Landau (ed.), Oxford studies in metaethics, 127-160. Clarendon.

Wedhawati, Wiwin, Erni Siti Nurlina, Edi Setiyanto, Restu Sukesti, Marsono \& I. Praptomo Baryadi. 2006. Tata bahasa jawa mutakhir [Javanese grammar]. Yogyakarta: Penerbit Kanisius.

Wertheimer, Roger. 1972. The significance of sense: Meaning, modality, and morality. Ithaca, NY: Cornell University Press.

Yalcin, Seth. 2010. Probability operators. Philosophy Compass 5(11). 916-937. https://doi.org/10.1111/j.1747-9991.2010.0036o.x. 
Weak necessity without weak possibility

Yalcin, Seth. 2016. Modalities of normality. In Nate Charlow \& Matthew Chrisman (eds.), Deontic modality, 230-255. Oxford: Oxford University Press. h ttps://doi.org/10.1093/acprof:oso/9780198717928.003.00o9.

Jozina Vander Klok

Universitetet i Oslo, Blindern

Department of Linguistics

and Scandinavian Studies

P.O. Box 1102, 0317 Oslo

Norway

j.v.klok@iln.uio.no
Vera Hohaus

The University of Manchester

Department of Linguistics

and English Language

Oxford Rd, Manchester M139PL

United Kingdom

vera.hohaus@manchester.ac.uk 